\title{
2016 WESTERN REGIONAL MEETING \\ PROGRAM AT-A-GLANCE \\ Carmel, California
}

\section{January 28-30, 2016}

\begin{tabular}{|c|c|}
\hline TIME & ACTIVITY \& LOCATION \\
\hline & THURSDAY, JANUARY 28, 2016 \\
\hline $8: 00 \mathrm{am}-5: 00 \mathrm{pm}$ & $\begin{array}{c}\text { Registration } \\
\text { Sunset Center - Entry Lobby }\end{array}$ \\
\hline $8: 00 \mathrm{am}-5: 00 \mathrm{pm}$ & $\begin{array}{l}\text { Speaker Ready Room } \\
\text { Sunset Center }\end{array}$ \\
\hline 9:00 am - 11:30 am & $\begin{array}{c}\text { WAP Symposium } \\
\text { Diseases without Borders } \\
\text { Studio } 105\end{array}$ \\
\hline $9: 30 \mathrm{am}-12: 00 \mathrm{pm}$ & $\begin{array}{c}\text { WSPR Council Meeting } \\
\text { Sunset Center - Bingham \#3 }\end{array}$ \\
\hline 11:00 am - 12:00 pm & $\begin{array}{l}\text { How to Choose a Residency with a Research Focus } \\
\text { Bring own lunch } \\
\text { Open to all students } \\
\text { Sunset Center - Chapman \#4 }\end{array}$ \\
\hline $11: 35 \mathrm{am}-12: 30 \mathrm{pm}$ & $\begin{array}{l}\text { New Investigator Workshops } \\
\text { (Intended for Fellows and Jr. Faculty - Additional charge of } \$ 10 \text { and lunch will be provided) } \\
\text { Finding Your Niche in Research } \\
\text { Nevin Wilson, MD, University of Nevada School of Medicine, Las Vegas } \\
\text { Marybeth Hogan, MD, University of Nevada } \\
\text { School of Medicine, Las Vegas } \\
\text { Sunset Center - Green Room }\end{array}$ \\
\hline 11:35 am - 12:00 pm & $\begin{array}{l}\text { WAP Business Meeting } \\
\text { Studio } 105\end{array}$ \\
\hline $12: 30 \mathrm{pm}-2: 30 \mathrm{pm}$ & $\begin{array}{l}\qquad \begin{array}{c}\text { Concurrent Sessions } \\
\text { Sunset Center }\end{array} \\
\text { Adolescent Medicine and General Pediatrics I - Carpenter Hall } \\
\text { Cardiovascular I - Promenade Lobby } \\
\text { Endocrinology and Metabolism I - Bingham \#3 } \\
\text { Health Care Research I - Babcock \#6 } \\
\text { Immunology and Rheumatology I - Chapman \#4 } \\
\text { Infectious Diseases I - Conductor's Room } \\
\text { Neonatal Pulmonary I - Rehearsal Room } \\
\text { Neonatology General I - Studio 105 }\end{array}$ \\
\hline $2: 35 p m-3: 25 p m$ & $\begin{array}{c}\text { Carmel Research Prize Recipient Presentation I } \\
\text { Cinnamon S. Bloss, PhD, University of California San Diego } \\
\text { Henry Lee, MD, Stanford University } \\
\text { (all invited) } \\
\text { Sunset Center - Studio } 105\end{array}$ \\
\hline
\end{tabular}




\begin{tabular}{|c|c|}
\hline TIME & ACTIVITY \& LOCATION \\
\hline $3: 30 p m-6: 00$ pm & $\begin{array}{l}\text { Concurrent Sessions } \\
\text { Sunset Center }\end{array}$ \\
\hline $6: 00$ pm - 7:30 pm & $\begin{array}{l}\text { Welcome Reception and Poster Session } \\
\text { Jointly sponsored by } \\
\text { WAFMR, WAP, WSCl, WSMRF, and WSPR } \\
\text { All welcome and encouraged to attend (Shuttle provided from Sunset Center) } \\
\text { Carmel Mission Inn - Carmelo Ballroom: } \\
3665 \text { Rio Road, Carmel, CA } 93923\end{array}$ \\
\hline 7:00 pm - 9:00 pm & $\begin{array}{c}\text { Abbott Nutrition WSPR Reception } \\
\text { Open to all WSPR members, trainees, and guests } \\
\text { Poseidon Room, La Playa Hotel }\end{array}$ \\
\hline 7:00 pm - 9:00 pm & $\begin{array}{l}\text { WAP Council Meeting } \\
\text { (by invitation only) } \\
\text { St. Tropez Restaurant - Dolores Avenue between Ocean and Seventh }\end{array}$ \\
\hline \multirow[t]{2}{*}{ 7:00 pm - 9:00 pm } & $\begin{array}{l}\text { WAFMR Business Meeting } \\
\text { (by invitation only) } \\
\text { Forge in the Forest }\end{array}$ \\
\hline & FRIDAY, JANUARY 29, 2016 \\
\hline 7:00 am - 8:00 am & $\begin{array}{l}\text { How Do I Join the WSMRF Student Board of Directors? } \\
\qquad \text { Carmel Mission Inn - Lobby }\end{array}$ \\
\hline $8: 00 \mathrm{am}-5: 00 \mathrm{pm}$ & $\begin{array}{c}\text { Registration } \\
\text { Sunset Center - Entry Lobby }\end{array}$ \\
\hline 8:00 am - 5:00 pm & $\begin{array}{l}\text { Speaker Ready Room } \\
\text { Sunset Center }\end{array}$ \\
\hline $8: 00$ am - 11:40 am & $\begin{array}{c}\text { Joint Plenary Session } \\
\text { Diseases without Borders } \\
\text { WAFMR, WSCI, WAP, and WSPR } \\
\text { Sunset Center - Theater } \\
\text { WSCI Outstanding Investigator Award } \\
\text { WSPR Abbott Nutrition David W. Smith Pediatric Trainee Research Award } \\
\text { WSPR Abbott Nutrition Lowell Glasgow Student Research Award } \\
\text { WSPR Abbott Nutrition Young Investigator Research Award } \\
\text { WSPR Joseph W. St. Geme, Jr. Education Award } \\
\text { E.E. Osgood Award } \\
\text { WAFMR Outstanding Investigator Award } \\
\text { WSPR Stanley Wright Lecture } \\
\text { WAP Distinguished Lecture } \\
\text { Mayo Soley Award Presentation }\end{array}$ \\
\hline
\end{tabular}




\begin{tabular}{|c|c|}
\hline TIME & ACTIVITY \& LOCATION \\
\hline $11: 15$ am - 12:15 pm & $\begin{array}{l}\text { Meet the Mentors: Lunch with Carmel Research Prize Recipients } \\
\text { Panel Discussion } \\
\text { (Intended for Students and Residents) } \\
\text { Cinnamon S. Bloss, PhD, University of California San Diego } \\
\text { Henry Lee, MD, Stanford University } \\
\text { Melanie Cree Green, MD, PhD, University of Colorado School of Medicine } \\
\text { Jose R Suarez, MD, MPH, PhD, University of California San Diego } \\
\text { (limited availability 45, Additional charge of } \$ 10 \text { and lunch will be provided) } \\
\text { Sunset Center - Studio } 105\end{array}$ \\
\hline $11: 40$ am - 12:30 pm & $\begin{array}{c}\text { Investigator Workshop } \\
\text { (Intended for Fellows and Jr. Faculty) } \\
\text { (Additional charge of } \$ 10 \text { and lunch will be provided) } \\
\text { How To Pick a Good Scientific Question } \\
\text { W. Conrad Liles, University of Washington } \\
\text { Sunset Center - Green Room }\end{array}$ \\
\hline $11: 40$ am - 12:00 pm & $\begin{array}{l}\text { WSCI Society Business Meetings } \\
\text { Sunset Center - Theater }\end{array}$ \\
\hline $11: 40$ am - 12:00 pm & $\begin{array}{l}\text { WSPR Business Meeting } \\
\text { Sunset Center - Theater }\end{array}$ \\
\hline $12: 30 \mathrm{pm}-2: 30 \mathrm{pm}$ & $\begin{array}{l}\qquad \begin{array}{c}\text { Concurrent Sessions } \\
\text { Sunset Center }\end{array} \\
\text { Adolescent Medicine and General Pediatrics II - Studio } 105 \\
\text { Cardiovascular III - Promenade Lobby } \\
\text { Endocrinology and Metabolism II - Bingham \#3 } \\
\text { Gastroenterology - Babcock \#6 } \\
\text { Genetics - Rehearsal Room } \\
\text { Neonatal Pulmonary III - Carpenter Hall } \\
\text { Neonatology General III - All Saints Church, Seccombe Hall } \\
\text { Neonatology - Perinatal Biology I - Chapman \#4 } \\
\text { Surgery II - Conductor's Room }\end{array}$ \\
\hline 1:00 pm - 5:30 pm & $\begin{array}{c}\text { California Thoracic Society Meeting } \\
\text { Quail Lodge } \\
8205 \text { Valley Greens Drive, Carmel, CA } 93923\end{array}$ \\
\hline 2:35 pm - 3:25 pm & $\begin{array}{c}\text { Carmel Research Prize Recipient Presentation II } \\
\text { Melanie Cree Green, MD, PhD, University of Colorado School of Medicine } \\
\text { Jose R Suarez, MD, MPH, PhD, University of California San Diego } \\
\text { (all invited) } \\
\text { Sunset Center - Studio } 105\end{array}$ \\
\hline 3:30 pm - 6:00 pm & $\begin{array}{l}\text { Concurrent Sessions } \\
\text { Sunset Center }\end{array}$ \\
\hline
\end{tabular}




\begin{tabular}{|c|c|}
\hline TIME & ACTIVITY \& LOCATION \\
\hline $6: 00 \mathrm{pm}-7: 30 \mathrm{pm}$ & $\begin{array}{c}\text { University of Washington Reception } \\
\text { All UW faculty, fellows, residents and students invited } \\
\text { Mission Ranch - } 26270 \text { Dolores Street }\end{array}$ \\
\hline $6: 15 p m-7: 15 p m$ & $\begin{array}{l}\text { Genetics and Morphology Club } \\
\text { Sunset Center - Rehearsal Room }\end{array}$ \\
\hline $6: 30 \mathrm{pm}-9: 30 \mathrm{pm}$ & $\begin{array}{c}\text { Western Respiratory Club Dinner } \\
\text { Quail Lodge -Ballroom } \\
8205 \text { Valley Greens Drive, Carmel, CA } 93923\end{array}$ \\
\hline \multirow[t]{2}{*}{$6: 30 p m-9: 00 p m$} & $\begin{array}{c}\text { Western Perinatal Club } \\
\text { LaPlaya Hotel }\end{array}$ \\
\hline & SATURDAY, JANUARY 30, 2016 \\
\hline $8: 00 \mathrm{am}-12: 00 \mathrm{pm}$ & $\begin{array}{c}\text { Speaker Ready Room } \\
\text { Sunset Center }\end{array}$ \\
\hline $8: 00 \mathrm{am}-10: 00 \mathrm{am}$ & $\begin{array}{c}\text { Registration } \\
\text { Sunset Center - Entry Lobby }\end{array}$ \\
\hline $8: 00$ am - 10:00 am & $\begin{array}{l}\qquad \begin{array}{c}\text { Concurrent Sessions } \\
\text { Sunset Center }\end{array} \\
\text { Adolescent Medicine and General Pediatrics III - Rehearsal Room } \\
\text { Community Health III - Conductor's Room } \\
\text { Endocrinology and Metabolism III - Bingham Room \#3 } \\
\text { General Internal Medicine and Aging - Babcock \#6 } \\
\text { Neonatology General V - Carpenter Hall } \\
\text { Neonatology Perinatal Biology II - Studio } 105 \\
\text { Pulmonary and Critical Care II - Promenade Lobby } \\
\text { Surgery IV - Green Room }\end{array}$ \\
\hline $10: 00 \mathrm{am}-10: 15 \mathrm{am}$ & Break \\
\hline $10: 15$ am - 11:45 am & $\begin{array}{l}\qquad \begin{array}{c}\text { Concurrent Sessions } \\
\text { Sunset Center }\end{array} \\
\text { Adolescent Medicine and General Pediatrics IV- Rehearsal Room } \\
\text { Health Care Research III - Babcock \#6 } \\
\text { Hematology and Oncology III - Green Room } \\
\text { Immunology and Rheumatology II - Conductor's Room } \\
\text { Neonatal Pulmonary IV - Bingham Room \#3 } \\
\text { Neonatology General VI - Carpenter Hall } \\
\text { Neonatology Perinatal Biology III - Promenade Lobby } \\
\text { Neuroscience III - Chapman \#4 }\end{array}$ \\
\hline $11: 50 \mathrm{am}-2: 00 \mathrm{pm}$ & $\begin{array}{l}\text { Society Officers Planning Meeting } \\
\text { (by invitation only) } \\
\text { Sunset Center - Studio } 105\end{array}$ \\
\hline $1: 30 \mathrm{pm}-5: 30 \mathrm{pm}$ & $\begin{array}{c}\text { California Thoracic Society Meeting } \\
\text { Quail Lodge }\end{array}$ \\
\hline
\end{tabular}




\section{CME Certification}

This Live activity, 2016 Western Regional Meeting, with a beginning date of January 28, 2016, has been reviewed and is acceptable for up to 21.50 Prescribed credits by the American Academy of Family Physicians. Physicians should claim only the credit commensurate with the extent of their participation in the activity.

AMA/AAFP Equivalency: AAFP Prescribed credit is accepted by the American Medical Association as equivalent to AMA PRA Category 1 credit (s) TM $^{\mathrm{TM}}$ toward the AMA Physician's Recognition Award. When applying for the AMA PRA, Prescribed credit earned must be reported as Prescribed, not as Category 1.

An electronic credit request/evaluation survey will be emailed to you after the program. This electronic survey will allow you to provide your evaluation of this educational activity in addition to requesting AMA PRA, Prescribed credit earned must be reported as Prescribed, not as Category 1.

You will receive the link and instructions in your email inbox on Monday, February 1, 2016. If you do not receive your link to the evaluation in your email inbox, please contact us at admin@afmr.org. Original certificates for this conference may be claimed until February 29, 2016. Duplicate certificates are available at any time.

We would also like to thank the following for reviewing the abstracts and to the Lead Reviewer's for organizing the sessions:

Margaret Adam
Kurt Albertine
Kathleen Angkustsiri
Jorge N. Artaza
Maralyssa Bann
Jennifer L. Barton
Michel Baudry
Arlin B. Blood
Yvette Bordelon
Laura D. Brown
Fred Buckner
Christopher Chang
Marie-Francoise Chesselet
Michel Chonchol
Keith K. Colburn
Lloyd Damon
Kevin Deane
Ian H. DeBoer
Thomas Deloughery
Sarah Dugan
Ravi Durvasula
Josephine M. Enciso
Erika Fernandez
Camille Fung
Renata Gallagher
Peter Ganz
David Gilbert
Joshua I. Goldhaber
Subhas Gupta
Kellie Hawkins
Deborah Huang

Kenneth E. Izuora

Vipul Jain

Lauren Jantzie

Marilyn Jones

Lisa Joss-Moore

Alberta Kong

Kristina Lee

Edward Lee

Henry C. Lee

Juan N. Lessing

W. Conrad Liles

Henry C. Lin

Carlin Long

Bryan J. McColgan

Philippe Montgrain

Yona Nicolau

Jorge Nieva

Lee $\mathrm{Pu}$

Mary Ramos

Ann Reynolds

Robert S. Ross

Michael Schivo

Neil Sun Rhodes

Nicole Tartaglia

Kristina M. Utzschneider

David Viskochil

Raj Vyas

James Wallace

Craig Wong

Clyde Wright 


\section{Western Regional Meeting Award Winners}

Leslie Colip, University of New Mexico Health Science Center

Yasmin Aghajan, University of California, San Diego

McHale Anderson, University of Washington School of Medicine

Eleonore Breuning, BC Children's Hospital

Amy Cruickshank, University of Oklahoma

Sarah Daley, University of Arizona

Shanlee Davis, University of Colorado

Sarah Dill, University of Colorado

Dawn Gano, University of California, San Francisco

Theodore Gobillot, Fred Hutchinson Cancer Research Center

Megan Gossling, University of Colorado

Linh Ho, University of Colorado School of Medicine

Lauren Jantzie, University of New Mexico

Naima Kotadia, University of British Columbia

Brooks Kuhn, UC Davis Medical Center

Julia Lee, UC Davis Medical Center

Jina Lim, University of California, Los Angeles

Ivy Lin, University of Arizona

Sonia Lin, University of Southern California

Katherine Lind, University of Colorado School of Medicine

Brianna MacQueen, University of Utah

Sidharth Mahapatra, University of Nebraska Medical Center

Deepti Mathur, LAC+USC Medical Center, Children's Hospital Los Angeles

Natalia Moss, University of New Mexico

Dilip Nagarkar, University of Washington

Maide Ozen, Stanford University School of Medicine

David Pavlik, University of New Mexico

Amelie Peisl, University of Colorado Medical School

Edmund Posadas, University of California, San Diego

Melody Rasouli, University of Southern California Keck School of Medicine

Rebecca Rieger, University of New Mexico

Katya Rubinow, University of Washington

Maura Ruzhnikov, Stanford University

Takeshi Saito, University of Southern California

Lawrence Shiow, University of California, San Francisco

Ann Simones, University of Minnesota, Masonic Children's Hospital

Sonia Solomon, Valley Children's Hospital

Caitlin Stiglmeier, University of Utah, Mota Fofalia Children's Hospital

Abhilasha Surampalli, University of California, Irvine

Clara Vu, Loma Linda University

Tarik Walker, University of Colorado School of Medicine

Brian Walsh, University of Colorado School of Medicine

Claudia Weinheimer, University of Utah

Theodore Wilson, University of Utah

Jonathan Yaghoubian, Western University of Health Sciences

Xin Yue, Cedars Sinai Medical Center

Evan Zahn, Cedars Sinai Medical Center
WSPR Mead Johnson Travel Award Winner

WAFMR/WAP Student Subspecialty Award Winner

WAFMR/WAP Student Subspecialty Award Winner

WAFMR Scholar Awardee

WAFMR Scholar Awardee

WAFMR/WAP Student Subspecialty Award Winner

WAFMR Scholar Awardee

WSCl Travel Award Winner

WSPR Mead Johnson Travel Award Winner

WAFMR/WAP Student Subspecialty Award Winner WSPR Mead Johnson Travel Award Winner

WAFMR/WAP Student Subspecialty Award Winner WSPR Abbott Nutrition Young Investigator Award WAFMR/WAP Student Subspecialty Award Winner

WAFMR Scholar Awardee

WSCI Travel Award Winner

WAFMR Scholar Awardee

WAFMR/WAP Student Subspecialty Award Winner

WSCl Travel Award Winner

WAFMR/WAP Student Subspecialty Award Winner

Abbott Subspecialty Award

WSCI Travel Award Winner

Abbott Subspecialty Award

Abbott Subspecialty Award

WAFMR/WAP Student Subspecialty Award Winner

WAFMR Scholar Awardee

WAFMR/WAP Outstanding Resident Award Winner

Abbott Subspecialty Award

WAFMR/WAP Student Subspecialty Award Winner

Abbott Subspecialty Award

Abbott Subspecialty Award

WSCl Travel Award Winner

WSPR Mead Johnson Travel Award Winner

WAFMR Outstanding Investigator Award Winner

WSPR Abbott Nutrition David W. Smith Pediatric Trainee Research Award Winner

WSPR Mead Johnson Travel Award Winner

WSPR Outstanding Resident Award Winner

WSCl Travel Award Winner

Abbott Subspecialty Award

WAFMR/WAP Student Subspecialty Award Winner

WAFMR Scholar Awardee

WSPR Abbott Nutrition Lowell Glasgow Student Research Award Winner

Abbott Subspecialty Award

WSPR Mead Johnson Travel Award Winner

WAFMR/WAP Student Subspecialty Award Winner

E.E. Osgood Award

WSCl Travel Award Winner 


\section{SPECIALTY CLUB ANNOUNCEMENTS}

Friday, January 29, 2016

\section{GENETICS AND MORPHOLOGY CLUB \\ 6:15 PM - 7:15 PM \\ Rehearsal Room - Sunset Center}

Genetic Unknowns and Rare Knowns

Contact person: Joseph Shieh and Jon Bernstein

\section{WESTERN PERINATAL CLUB}

Sponsored by the Perinatal Sections of AAP Districts VIII and IX and

The California Association of Neonatologists LaPlaya Carmel Hotel

6:00 PM - Reception

6:30 - 7:30 PM

Perinatal Briefing

DELAYED CORD CLAMPING: TRANSFERRING EVIDENCE INTO PRACTICE

Featured Speaker: Ryan McAdams, MD, University of Washington

Supported by Mead Johnson Nutrition 


\section{WESTERN ASSOCIATION OF PHYSICIANS}

\section{DISEASES WITHOUT BORDERS}

Thursday, January 28, 2016

9:00 AM - 11:30 AM

Sunset Center - Studio 105

W. Conrad Liles and Ravi Durvasula, Presiding

9:00 THE GLOBAL LEISHMANIA EPIDEMIC: TRANSLATIONAL STRATEGIES FOR CONTROL.

Abhay Satoskar, Ohio State University School of Medicine

9:45 GLOBAL TRENDS IN CHAGAS DISEASE.

Caryn Bern, University of California, San Francisco School of Medicine

10:30 BREAK

10:45 GLOBAL BURDEN OF CARDIOVASCULAR DISEASE.

Gregory A. Roth, University of Washington

11:30 ADJOURN

11:35 WAP BUSINESS MEETING

\section{INVESTIGATOR WORKSHOP}

Thursday, January 28, 2016
11:35 AM - 12:30 PM

The American Federation for Medical Research and the Tri-Societies are pleased to sponsor a workshop for Fellows and Junior Faculty. Additional charge of $\$ 10$ and lunch will be provided.

\section{FINDING YOUR NICHE IN RESEARCH}

Nevin Wilson, MD, University of Nevada School of Medicine, Las Vegas

Marybeth Hogan, MD, University of Nevada School of Medicine, Las Vegas

\section{Sunset Center - Green Room}




\section{CONCURRENT SESSIONS}

Thursday, January 28, 2016

12:30 PM - 2:30 PM

Jointly sponsored by

WESTERN SECTION AMERICAN FEDERATION FOR MEDICAL RESEARCH

WESTERN SOCIETY FOR CLINICAL INVESTIGATION

WESTERN ASSOCIATION OF PHYSICIANS

WESTERN SOCIETY FOR PEDIATRIC RESEARCH

WESTERN STUDENT MEDICAL RESEARCH FORUM

Adolescent Medicine and General Pediatrics I

Carpenter Hall

Cardiovascular I

Promenade Lobby

Endocrinology and Metabolism I

Bingham \#3

Health Care Research I

Babcock \#6

Immunology and Rheumatology I

Chapman \#4

Infectious Diseases I

Conductor's Room

Neonatal Pulmonary I .

Rehearsal Room

Neonatology - General I Studio 105

Adolescent Medicine and General Pediatrics I

Carpenter Hall (Sunset Center)

Craig Wong and Walter Dehority, Presiding

12:30 PREDICTING HEIGHT IN A PEDIATRIC INTENSIVE CARE UNIT USING ULNAR LENGTH.

MA Rasouli, CJ Newth, RG Khemani and PA Ross, Los Angeles, CA. University of Southern California Keck

School of Medicine (Abbott Subspecialty Award)

Abstract 1

12:45 MODALITY OF TREATMENT OF PATIENTS WITH DIARRHEAL HUS IN ACUTE RENAL FAILURE DOES NOT AFFECT LONG TERM OUTCOME AND SURVIVAL IN PEDIATRIC PATIENTS.

S Solomon, Fresno, CA. Valley Children's Hospital (WSPR Outstanding Resident Award Winner)

Abstract 2

1:00 AN UNUSUAL PRESENTATION OF A HIGHLY MALIGNANT TUMOR.

$S$ Bhoopalan and SU Das, Las Vegas, NV. University of Nevada School of Medicine

Abstract 3

1:15 COMPARISON OF HEAD CT USAGE BY PEDIATRIC EMERGENCY MEDICINE PROVIDERS IN CHILDREN WITH HEAD INJURY BEFORE AND AFTER PECARN GUIDELINES.

K Morgan, M Hudkins, H Chandnani, D Chao and J Fisher, Las Vegas, NV; Loma Linda, CA and San Diego, CA. University of Nevada School of Medicine

Abstract 4

1:30 A RETROSPECTIVE DATABASE REVIEW OF POTENTIAL RISK FACTORS, PREDICTORS AND INCIDENCE OF POST-CONCUSSION SYNDROME IN PEDIATRIC PATIENTS.

Z Oleskey and M Mortazavi, Tucson, AZ. University of Arizona College of Medicine

Abstract 5

1:45 EVALUATING TRENDS IN HEADACHE AND REVISION SURGERY FOLLOWING CRANIAL VAULT REMODELING FOR CRANIOSYNOSTOSIS.

E Pellicer, B Saltzmann and E Gallagher, Seattle, WA. University of Washington / Seattle Children's Hospital 
2:00 ASSOCIATION BETWEEN MINIMAL RESIDUAL DISEASE AND MITOCHONDRIAL DNA IN CHILDHOOD B-CELL LYMPHOMA.

T Shieh, M Ueoka, K Kaneta, C Nakamura, J Kuroda, M Agsalda-Garcia and B Shiramizu, Honolulu, HI. John A. Burns School of Medicine

Abstract 7

2:15 HOSPITAL COURSE OF PEDIATRIC PATIENTS ADMITTED FOR INTUSSUSCEPTION.

J Orosco and B Afghani, Anaheim, CA, Long Beach, CA and Irvine, CA. Children's Hospital of Orange County

Abstract 8

\section{Cardiovascular I}

Promenade Lobby (Sunset Center)

Peter Ganz and Carlin Long, Presiding

12:30 DOES INFECTION TRIGGER THE IMMUNE SYSTEM FOR REJECTION OR ANTIBODY PRODUCTION AFTER HEART TRANSPLANTATION?

A Lipson, T Aintablian, M Hamilton and JA Kobashigawa, Los Angeles, CA. Cedars-Sinai Medical Center

Abstract 9

12:45 IS CHRONIC LUNG DISEASE FEV1/FVC $<70 \%$ A MARKER FOR PROLONGED INTUBATION IMMEDIATELY POST-TRANSPLANTATION?

T Manayan, T Aintablian, S Siddiqui, M Hamilton and JA Kobashigawa, Los Angeles, CA.

Cedars-Sinai Medical Center

Abstract 10

1:00 RESOURCE UTILIZATION IN THE STATE OF CALIFORNIA FOR NEONATES WITH HYPOPLASTIC LEFT HEART SYNDROME.

M Luu, PS Friedlich, J Votava-Smith, J Pruetz, R Subramanyan and A Lakshmanan, Los Angeles, CA. Children's Hospital Los Angeles

1:15 IS THE INCIDENCE OF ATRIAL SEPTAL DEFECTS INCREASED IN EXTREMELY LOW BIRTH WEIGHT INFANTS?

C Hayek, M Ebrahimi, R Cayabyab, M Uzunyan, R Ramanathan and B Siassi, Los Angeles, CA. LAC+ USC

Medical Center

Abstract 12

1:30 TRANS-CATHETER CLOSURE OF PATENT DUCTUS ARTERIOSUS IN SEVERELY PREMATURE NEONATES: A NEW TECHNIQUE FOR A VEXING PROBLEM.

D Peck, E Zahn, R Garg, A Phillips, M McRae, C Simmons, P Nevin and K Basacker, Los Angeles, CA. Cedars-Sinai (WSCI Travel Award Winner)

Abstract 13

1:45 CELIAC TRUNK CALCIFICATION: ASSOCIATIONS WITH RISK FACTORS, SYSTEMIC CALCIFIED ATHEROSCLEROSIS, AND MORTALITY.

T Lin and M Allison, San Diego, CA. University of California, San Diego

Abstract 14

2:00 ORGAN TURN DOWN AT A SINGLE CENTER: DONOR HEART ORGAN TURN DOWN, IS IT RATIONAL? E Norris, TAintablian, M Hamilton and JA Kobashigawa, Los Angeles, CA. Cedars-Sinai Medical Center (WAFMR/ WAP Student Subspecialty Award Winner) 
Endocrinology and Metabolism I

Bingham Room \#3 (Sunset Center)

Kristen Nadeau and Stephanie Page, Presiding

12:30 GROWTH HORMONE IS INVOLVED IN HUMAN COLON TUMOR GROWTH.

CA Bailey, V Chesnokova, S Zonis and S Melmed, Chino Hills, CA and Los Angeles, CA. Cedars-Sinai Medical Center

Abstract 16

12:45 FOLLISTATIN PROTECTS AGAINST DIET-INDUCED OBESITY AND IMPROVES GLOBAL

METABOLOMICS IN ADIPOSE TISSUES.

$R$ Singh, ST Reddy, M Braga, X Liu, M Parveen, D Stout, K Reue, S Pervin, Los Angeles, CA. Charles R. Drew University

Abstract 17

1:00 ESCALATING DOSES OF TESTOSTERONE INCREASE LEAN BODY MASS AND HEMATOCRIT

WITHIN THREE MONTHS, IN HEALTHY MEDICALLY CASTRATE MEN.

A Thirumalai, L Cooper, J Amory and S Page, Seattle, WA. University of Washington

Abstract 18

1:15 CYSTIC FIBROSIS RELATED DIABETES IS A PREDICTOR OF INCREASED INCIDENCE OF CHRONIC PSEUDOMONAS AERUGINOSA.

MA Szkudlinska, M Crull, E Caldwell, ML Aitken and CH Goss, Seattle, WA. University of Washington

Abstract 19

1:30 NON-ALCOHOLIC FATTY LIVER DISEASE IN OBESE ADOLESCENT GIRLS IS ASSOCIATED WITH

INSULIN RESISTANCE AND PREDICTORS OF CARDIOMETABOLIC DISEASE.

RL Sewell, L Pyle, A Scherzinger, M Cree-Green and K Nadeau, Aurora, CO. University of Colorado School of Medicine

Abstract 20

CANCELLED

Abstract 21

$1: 45$

THE EFFECT OF OBESITY AND INSULIN RESISTANCE ON REPRODUCTIVE FUNCTION IN EARLY PUBERTAL BOYS.

M Tsang, K Nadeau, A Hilkin, J Chosich, PE Zeitler, N Santoro and M Kelsey, Berkeley, CA and Aurora, CO.

University of California, Berkeley

Abstract 22

Health Care Research I

Babcock \#6 (Sunset Center)

David Evans and Brian Walker, Presiding

12:30 INTENSE THERAPEUTIC ULTRASOUND IN THE MANAGEMENT OF PATIENTS WITH CHRONIC PLANTAR FASCIITIS.

DN Christensen, L Latt and A McNelly, Tucson, AZ. University of Arizona

Abstract 23

12:45 A BIOFEEDBACK SMART CANE TO REDUCE KNEE LOADING ASSOCIATED WITH OSTEOARTHRITIS.

M Hinchcliff, R Routson, A Segal, P Suri, J Czerniecki and P Aubin, Seattle, WA. University of Washington

Abstract 24

1:00 A REVIEW OF THE CHARACTERISTICS OF VALIDATED QUALITY OF LIFE (QOL) PATIENT REPORTED OUTCOME MEASURES (PROMS) IN PAEDIATRIC PLASTIC SURGERY.

JM Roller, RJ Courtemanche and DJ Courtemanche, Vancouver, BC, Canada. British Columbia's Children Hospital

Abstract 25 
1:15 REDUCING EXPOSURE OF HEALTH CARE JANITORIAL WORKERS TO PERACETIC ACID, SPORICIDAL TO CLOSTRIDIUM DIFFICILE.

LW Raymond, P Klasing, M Daniel and J Fuller, Charlotte, NC. University of North Carolina, Chapel Hill

1:30 EMERGENCY PHYSICIAN UTILIZATION OF ULTRASOUND IN ARIZONA.

MT Wyman, R Amini, NC Hernandez and S Adhikari, Tucson, AZ. University of Arizona College of Medicine

1:45 EXPLORING PALLIATIVE CARE CONSULTATIONS IN THE NEURO-INTENSIVE CARE UNIT.

LN Tran, A Back and C Creutzfeldt, Seattle, WA. University of Washington School of Medicine

Abstract 28

2:00 FACTORS AFFECTING PATIENTS' DISCUSSIONS ABOUT END-OF-LIFE CARE.

$S$ Fakhri, R Engelburg, L Downey and JR Curtis, Covington, WA and Seattle, WA. University of Washington

Abstract 29

2:15 SEROLOGIC IMMUNITY AGAINST VARICELLA, MUMPS, RUBEOLA, RUBELLA AND HEPATITIS B IN HEALTH CARE APPLICANTS WITH INDETERMINATE IMMUNIZATION HISTORY.

LW Raymond, A McWilliams and L Crutchfield, Charlotte, NC. University of North Carolina, Chapel Hill

Abstract 30

Immunology and Rheumatology I

Chapman \#4 (Sunset Center)

Kevin Deane, Presiding

12:30 ALTERATIONS IN THE COLONIC MICROBIOME PRECEDE THE DEVELOPMENT OF RHEUMATOID ARTHRITIS.

JD Hendrickson, G Mehta, N Banda, C Robertson, D Frank, K Demourelle, K Deane and K Kuhn, Aurora, CO.

University of Colorado

Abstract 31

12:45 TREATMENT OF IGG4-RELATED PACHYMENINGITIS IN A PATIENT WITH STEROID

INTOLERANCE: THE ROLE OF EARLY USE OF RITUXIMAB.

V Gospodarev, JR Câmara, V Chakravarthy, R Dietz, M Wood, A Perry, K De Los Reyes and R Raghavan, San Francisco, CA and Loma Linda, CA. Loma Linda University School of Medicine

Abstract 32

1:00 CLINICAL AND DEMOGRAPHIC FACTORS ASSOCIATED WITH FATIGUE IN SPONDYLOARTHRITIS. DT Nhan, J Walsh, A Reimold and L Caplan, Aurora, CO, Dallas, TX and Salt Lake City, UT. University of Colorado School of Medicine

Abstract 33

1:15 DETERMINING THE ROLE OF THE TYK2 PROTECTIVE VARIANT P1104A IN INTERLEUKIN-12 SIGNALING AND HELPER T CELL TYPE 1 POLARIZATION.

A Misakian, Seattle, WA. University of Washington School of Medicine

Abstract 34

1:30 SPUTUM IGG AND IGA ANTI-CYCLIC CITRULLINATED PROTEIN ANTIBODIES IN SUBJECTS AT RISK FOR RHEUMATOID ARTHRITIS.

L Ho, K Demoruelle, M Weisman, M Parish, M Mahler, A Seaman, J Norris, M Holers and K Deane, Littleton, CO; Los Angeles, CO and San Diego, CA. University of Colorado School of Medicine (WAFMR/WAP Student Subspecialty Award Winner)

Abstract 35

1:45 LABORATORY ASSAYS FOR AIDING THE DIAGNOSIS OF CHRONIC URTICARIA.

TB Martins, RA Teufel and HR Hill, Salt Lake City, UT. ARUP Institute for Clinical and Experimental Pathology

Abstract 36 
2:00 GRANZYME A IS INCREASED IN PLATELETS FROM OLDER ADULTS, LEADING TO IL-8 AND MCP-1 CYTOKINE SYNTHESIS BY TARGET MONOCYTES.

A Bhatnagar, R Campbell, B Manne, A Weyrich and MT Rondina, Sandy, UT. University of Utah

Abstract 37

2:15 TUMOR NECROSIS FACTOR-ALPHA (TNF-A) RESPONSE AND MYCOBACTERIUM TUBERCULOSIS

(MTB) REPLICATION IN HSP90B1 KNOCKDOWN MACROPHAGES.

A Ajuogu, A Graustein and T Hawn, Seattle, WA. University of Washington

Abstract 38

Infectious Diseases I

Conductor's Room

Ravi Durvasula, Fred Buckner and David Gilbert, Presiding

12:30 USE OF ANTIBIOTICS IN TREATMENT OF CHILDREN DIAGNOSED WITH ESCHERICHIA COLI 0157: H7 DIARRHEA AND RISK OF DEVELOPING HEMOLYTIC UREMIC SYNDROME (HUS): REVIEW OF THE LITERATURE.

NN More, N Cheranda, J Rozenblit, J Kim, Y Kim, N Baskaran, M Vyakaranam and B Afghani, Irvine, CA and Orange, CA. University of California, Irvine

Abstract 39

12:45 HIV TESTING, STATUS, AND TREATMENT AMONG PATIENTS AT THE UGANDA CANCER INSTITUTE.

M Ghadrshenas, R Bender Ignacio and A Duerr, Seattle, WA. University of Washington

Abstract 40

1:00 NON-TYPE B HAEMOPHILUS INFLUENZAE PYOGENIC ARTHRITIS IN CHILDREN.

DF Pavlik, JJ Johnston and W Dehority, Albuquerque, NM. University of New Mexico

Abstract 41

1:15 ROLE OF IGG SUBCLASSES IN MUCOSAL DEFENSE OF STREPTOCOCCUS PNEUMONIAE.

$M W u$, J Rahkola and E Janoff, Aurora, CO. University of Colorado Denver

Abstract 42

1:30 USE OF ANTIBIOTICS RESERVED FOR RESISTANT GRAM-NEGATIVE INFETIONS AT

FREE-STANDING U.S. CHILDREN'S HOSPITALS FROM 2004 TO 2014.

M Jelic, AL Adler, A Miles-Jay, SJ Weissman, MP Kronman and DM Zerr, Seattle, WA. University of Washington

Abstract 43

1:45 CYTOTOXIC FUNCTION OF ANTIBODIES PRODUCED BY HIV-SPECIFIC B-CELLS IN AN INFECTED INFANT.

T Gobillot, C Simonich and J Overbaugh, Seattle, WA. Fred Hutchinson Cancer Research Center (WAFMR/WAP Student Subspecialty Award Winner)

Abstract 44

Neonatal Pulmonary I

Rehearsal Room (Sunset Center)

Arlin B. Blood and Clyde Wright, Presiding

12:30 NEONATAL LUNG EXPRESSION OF IL-1 ALPHA IN RESPONSE TO SYSTEMIC INFLAMMATION.

BE Butler, S McKenna and C Wright, Denver, CO. University of Colorado

Abstract 45

12:45 YAP-HIPPO VASCULAR SIGNALING DRIVES LUNG MORPHOGENEIS AND IS DYSREGULATED IN HYPEROXIA-INDUCED NEONATAL LUNG INJURY.

MS Sandoval, T Shishoian, R Sakurai, E Tsai, R Stockton and VK Rehan, Torrance, CA. Los Angeles Biomedical Research Institute

Abstract 46 
1:00 CORRECTION FOR ALTITUDE SIGNIFICANTLY CHANGES REPORT RATES FOR

BRONCHOPULMONARY DYSPLASIA.

K Gulliver and B Yoder, Salt Lake City, UT. University of Utah

1:15 TARGETED INVESTIGATION OF NOVEL MESENCHYMAL STEM CELL BIOMARKERS OF BRONCHOPULMONARY DYSPLASIA IN PREMATURELY BORN INFANTS.

RG LaGrandeur, F Bany-Mohammed, C Uy, DM Cooper and M Aslam, Orange, CA. University of California Irvine Medical Center

Abstract 48

1:30 NEONATAL HEPATIC COX2 EXPRESSION IS MEDIATED VIA AN NFאB-DEPENDENT MECHANISM FOLLOWING INFLAMMATORY STRESS.

S McKenna, BE Butler and CJ Wright, Aurora, CO. University of Colorado

1:45 EFFECT OF ELECTRO-ACUPUNCTURE ON OFFSPRING LUNG DEVELOPMENT FOLLOWING NICOTINE EXPOSURE DURING PREGNANCY AND LACTATION.

$R$ Sakurai, J Liu and VK Rehan, Torrance, CA. Los Angeles Biomedical Research Institute at Harbor-UCLA

Medical Center

Abstract 50

2:00 TREATMENT WITH AN ANTI-SFLT-1 MONOCLONAL ANTIBODY IMPROVES LUNG STRUCTURE AND PREVENTS PULMONARY HYPERTENSION IN AN EXPERIMENTAL MODEL OF BRONCHOPULMONARY DYSPLASIA DUE TO PREECLAMPSIA IN INFANT RATS.

A Peisl, G Seedorf, B Wallace, D Keefe and SH Abman, Aurora, CO and Cambridge, MA. University of Colorado Medical School (Abbott Subspecialty Award)

Abstract 51

2:15 LARYNGEAL MASK AIRWAY FOR SURFACTANT ADMINISTRATION IN NEONATES.

KD Roberts, N Finer, A Lampland, T Leone, J Tipnis, T Merritt, E Stepka, J Kessel, W Rich, K Rudser, R Brown and M Mammel, Minneapolis, MN, St Paul, MN; San Diego, CA, Loma Linda, CA, and Madison, WI. University of Minnesota Masonic Children's Hospital

Abstract 52

Neonatology General I

Studio 105 (Sunset Center)

Carlos Ramos and Erika Fernandez, Presiding

12:30 THE SPLANCHNIC-CEREBRAL OXYGENATION RATIO DECREASES DURING FEEDINGS IN ANEMIC PRETERM INFANTS.

K Braski, M Loertscher, C Rau, K Weaver Lewis and M Baserga, Salt Lake City, UT and Murray, UT. University of Utah

Abstract 53

12:45 BLEEDING RISK FACTORS IN NEONATES RECEIVING FISH OIL FOR INTESTINAL FAILURE ASSOCIATED LIVER DISEASE.

KM Keegan, RS Venick, JC Dunn, SB Shew, G Wegrzyn and KL Calkins, Los Angeles, CA. University of California, Los Angeles

Abstract 54

1:00 CLINICAL FACTORS RELATED TO NEONATAL GROWTH IN CONGENITAL DIAPHRAGMATIC HERNIA.

RH Beckert, L Lusk, EJ Yee and R Keller, Washington and San Francisco, CA. University of California, San Francisco

1:15 EFFECTS OF PREMATURITY, BIRTH WEIGHT AND POSTNATAL AGE ON PRETERM INFANTS' HYPERCALCIURIA.

S Malone Jenkins, G Chan, M Grinsell and K Weaver Lewis, Salt Lake City, UT and Murray, UT. University of Utah 
1:30 EVALUATING ALTERNATIVE APPROACHES TO THE MANAGEMENT OF INFANTS BORN TO MOTHERS WITH CHORIOAMNIONITIS.

A Jan, R Ramanathan and R Cayabyab, Los Angeles, CA. LAC+USC Medical Center

1:45 LOW FREQUENCY RHYTHMIC WOMB-LIKE SOUNDS MODIFY AUTONOMIC ACTIVITY IN PREMATURE NEONATES.

JJ Parga, RM Harper, H Karp, K Kesavan and L Zeltzer, Santa Monica, CA and Los Angeles, CA. David Geffen School of Medicine at UCLA

Abstract 58

2:00 REGIONALIZATION OF CARE AND OUTCOMES FOR NEONATES WITH CONGENITAL DIAPHRAGMATIC HERNIA IN CALIFORNIA 2006-2010.

A Song, PS Friedlich, R Chapman, R Burke, J Upperman, J Stein and A Lakshmanan, Los Angeles, CA. Children's Hospital Los Angeles SKIN.

J Foreman, S McConaghy, B Zlotoff, S Stepenaskie and RK Ohls, Albuquerque, NM. University of New Mexico School of Medicine 
CARMEL RESEARCH PRIZE RECIPIENT PRESENTATION I

Jointly sponsored by

WESTERN SECTION AMERICAN FEDERATION FOR MEDICAL RESEARCH
WESTERN SOCIETY FOR CLINICAL INVESTIGATION
WESTERN ASSOCIATION OF PHYSICIANS
WESTERN SOCIETY FOR PEDIATRIC RESEARCH
WESTERN STUDENT MEDICAL RESEARCH FORUM
Sunset Center - Studio 105
Thursday, January 28,2016
$2: 35$ PM - 3:25 PM

Ravi Durvasula and W. Conrad Liles, Presiding

2:35 IMPACT OF PRIVACY ENVIRONMENTS FOR PERSONAL HEALTH DATA ON PATIENTS.

Cinnamon S. Bloss, PhD, University of California San Diego

3:00 STUDYING THE TRANSLATION OF EVIDENCE INTO PRACTICE AND IMPLEMENTATION IN

PERINATAL MEDICINE.

Henry Lee, MD, Stanford University

\author{
CONCURRENT SESSIONS \\ Thursday, January 28, 2016 \\ 3:30 PM - 6:00 PM \\ Jointly sponsored by \\ WESTERN SECTION AMERICAN FEDERATION FOR MEDICAL RESEARCH \\ WESTERN SOCIETY FOR CLINICAL INVESTIGATION \\ WESTERN ASSOCIATION OF PHYSICIANS \\ WESTERN SOCIETY FOR PEDIATRIC RESEARCH \\ WESTERN STUDENT MEDICAL RESEARCH FORUM
}

Cardiovascular II

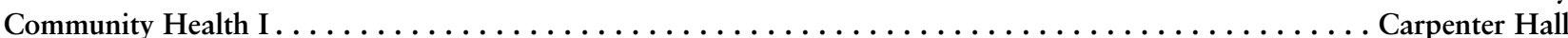

Global Health ............................................. Conductor's Room

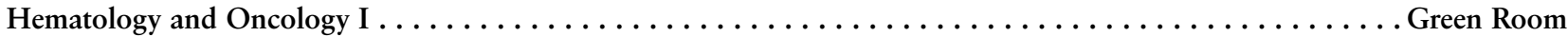

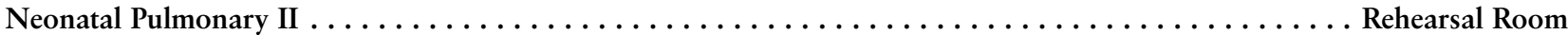

Neonatology General II. . . . . . . . . . . . . . . . . . . . . . . . . . . . . . . .

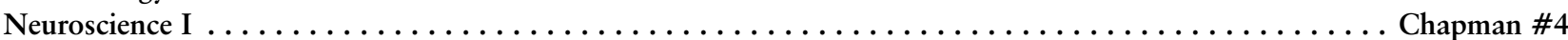

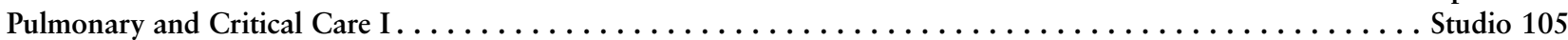

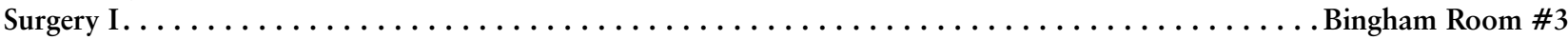

\title{
Cardiovascular II
}

Promenade Lobby (Sunset Center)

Robert S. Ross and Peter Ganz, Presiding

3:30 State-of-the-Art Speaker

BIOLOGY OF CARDIOVASCULAR AGING.

Peter Ganz, University of California, San Francisco

4:00 PEDIATRIC EKG TEACHING IN UCSF FRESNO PEDIATRIC RESIDENCY.

$R$ Manalo, Fresno, CA. University of California, Fresno 
4:15 VENTRICULAR FIBRILLATION WAVEFORM MEASURES DO NOT DISTINGUISH BETWEEN

ISCHEMIC AND NON-ISCHEMIC ETIOLOGY OF CARDIAC ARREST.

D Hidano, J Coult and TD Rea, Seattle, WA. University of Washington School of Medicine

Abstract 62

4:30 EFFECTS OF TUMOR NECROSIS FACTOR- $\alpha$ IN AN IN VITRO MODEL OF AORTIC VALVE STENOSIS.

J Lim, A Ehsanipour, A Wu, J Lu, T Pedego, C Walthers, S Seidlits, L Demer and Y Tintut, Los Angeles, CA.

University of California, Los Angeles (WAFMR Scholar Awardee)

Abstract 63

4:45 THE IMPACT OF CARDIAC TRANSPLANT REJECTION BY TIME POST-TRANSPLANTATION.

K Bucher, T Aintablian, M Hamilton and JA Kobashigawa, Los Angeles, CA. Cedars-Sinai Medical Center

Abstract 64

5:00 IDENTIFYING DISABLED PATIENTS AFTER HEART TRANSPLANTATION: WHAT MAKES SENSE?

A Aharonyan, T Aintablian, M Hamilton and JA Kobashigawa, Los Angeles, CA. Cedars-Sinai Medical Center

Abstract 65

5:15 MATERNAL HIGH FAT DIET AND DEVELOPMENTAL ORIGINS OF MYOCARDIAL DYSFUNCTION.

$H$ Wilde, Y Yang, E Zinkhan, B Yu, L Joss-Moore and TA Miller, Salt Lake City, UT. University of Utah

Abstract 66

5:30 CHARACTERIZATION OF HEART TRANSPLANT PATIENTS WITH RAPIDLY PROGRESSIVE CARDIAC

ALLOGRAFT VASCULOPATHY.

TAintablian, G Rodriguez, M Hamilton and JA Kobashigawa, Los Angeles, CA. Cedars-Sinai Medical Center

Abstract 67

5:45 SEIZURES POST HEART TRANSPLANTATION: WHAT ARE THE RISK FACTORS?

$K$ Soghoyan, T Aintablian, S Siddiqui, M Hamilton and JA Kobashigawa, Los Angeles, CA. Cedars-Sinai Medical Center

Abstract 68

Community Health I

Carpenter Hall

Mary Barinaga, Presiding

3:30 EFFECTS OF BODY MASS INDEX, SELF PERCEPTION AND CULTURE ON SELF ESTEEM IN CHILDREN.

KE Ta-ala, S Riantawan, M Chau, N Malika and M Baum, Loma Linda, CA. Loma Linda University

Abstract 69

3:45 IMPLEMENTING TEAM-BASED HEALTH PROMOTION PROGRAMS FOR YOUTH IN OREGON CORRECTIONAL FACILITIES.

E McCallum, M Smith, D Elliot, L Goldberg, K Racer and R Martin, Portland, OR and Salem, OR. Oregon Health and Science University

Abstract 70

4:00 A SURVEY ON COLLEGE STUDENTS SEEKING HEALTHCARE FROM A UNIVERSITY STUDENT HEALTH CENTER: USE AND INTERESTS IN COMPLEMENTARY AND ALTERNATIVE MEDICINE. J Nguyen, RJ Patel, MA Liu and AL Nguyen, Irvine, CA and Tucson, AZ. University of California, Irvine

Abstract 71

4:15 ADDRESSING BEHAVIORAL HEALTH IN SENIOR CITIZENS THROUGH A PILOT LAUGHTER

THERAPY CLUB IN PALMER, ALASKA.

NK Munger, Seattle, WA. University of Washington School of Medicine

Abstract 72 
4:30 IMPROVING CONCUSSION EDUCATION, DIAGNOSIS, AND MANAGEMENT IN COULEE DAM, WA THROUGH THE DEVELOPMENT OF A PARTNERED CONCUSSION PROTOCOL.

K Unruh, Seattle, WA. University of Washington School of Medicine

4:45 EFFECTS OF FOOD AS POSITIVE REINFORCEMENT AND CHILD'S BODY MASS INDEX.

S Riantawan, KE Ta-ala, M Chau, N Malika and M Baum, La Habra, CA and Loma Linda, CA. Loma Linda University

Abstract 74

5:00 PARENTAL GUIDANCE OF MEAL PORTIONS AND CHILDHOOD OBESITY.

M Chau, KE Ta-ala, S Riantawan, N Malika and M Baum, Loma Linda, CA. Loma Linda University School of Medicine

Abstract 75

5:15 EXAMINING BARRIERS TO EARLY IDENTIFICATION OF ASD IN IMMIGRANT PEDIATRIC PRIMARY CARE PATIENTS.

TD Walker, Aurora, CO. University of Colorado School of Medicine (WAFMR Scholar Awardee)

Abstract 76

5:30 A MULTIFACETED SUICIDE PREVENTION CAMPAIGN FOR RURAL MONTANA.

E Schiedermayer, Seattle, WA. University of Washington School of Medicine

Abstract 77

5:45 LESSONS LEARNED FROM ADOLESCENT PEER EDUCATORS WORKING TO EFFECT CHANGE IN ADOLESCENT HEALTH BEHAVIORS.

C Fields, S Cardenas, G Bookman, K Colwell and R Kinman, Fresno, CA and Madera, CA. Fresno High School Abstract 78

Global Health

Conductor's Room

Tom Nighswander, Presiding

3:30 NEEDS ASSESSMENT OF PRE-HOSPITAL CARE IN NICARAGUA: ADMINISTRATORS' PERSPECTIVES. L Marcia, R Leuchter, J Mitchel and D Orellana, Los Angeles, CA. David Geffen School of Medicine

Abstract 79

3:45 UNDERSTANDING THE CHALLENGES FOR TREATMENT OF HYPERTENSION IN RURAL VIETNAM. $D$ Veith, A Fitzpatrick and T Tam, Seattle, WA and Can Tho, Viet Nam. University of Washington School of Medicine

Abstract 80

4:00 ASSESSMENT OF CLEAN WATER FACILITY USAGE AFTER EDUCATIONAL INTERVENTION AND WATER INFRASTRUCTURE IMPROVEMENTS IN A REMOTE HIMALAYAN SCHOOL.

D Raff, B Smith, J Bhatla, C Bhatla, D Soni, B Cheung, K Shih, M Smith, S Browne, T Skutezky, J Fairley and V Kapoor, Vancouver, BC, Canada. University of British Columbia

Abstract 81

4:15 DEMOGRAPHICS OF POST-BURN CONTRACTURE PATIENTS TREATED IN CAMBODIA.

DR Tower, N Markadakis, K Vanna and JG Gollogly, Seattle, WA and Phnom Penh, Cambodia. University of Washington School of Medicine

4:30 MULTILINGUAL INTIMATE PARTNER VIOLENCE SCREENING AND RESOURCE CARD.

N Tan, Seattle, WA. University of Washington

4:45 TEACHING GOOD COMPLEMENTARY FEEDING PRACTICES TO LOW-LITERACY HEALTH PROMOTORS IN PERU.

T Shah, Seattle, WA. University of Washington School of Medicine 
5:00 FACILITY ASSESSMENT FOR MATERNAL AND NEONATAL HEALTH INTERVENTIONS IN RURAL NEPAL.

SM Folsom, B Fassl, A Sherpa, J Maddox, W Kopp and D Levy, Salt Lake City, UT and Phaplu, Nepal. University of Utab School of Medicine

Abstract 85

5:15 COMMUNITY PERCEPTIONS AND KNOWLEDGE OF MENTAL ILLNESS IN RURAL KENYA.

N Kotadia, S Walton, L Matheson, D Webster and V Kapoor, Vancouver, BC, Canada. University of British Columbia (WAFMR/WAP Student Subspecialty Award Winner)

Abstract 86

5:30 IMPROVING THE HEALTH OF WOMEN \& CHILDREN IN MIGRANT COMMUNITIES.

C Stiglmeier, M Patel and B Fassl, Syracuse, NY and Sinor Taluka, India. University of Utah (WSCI Travel Award Winner)

Abstract 87

5:45 A COMMUNITY-DRIVEN PILOT PROGRAM TO INCREASE BASIC PEDIATRIC HEALTH KNOWLEDGE AMONGST CHILD CARETAKERS IN KARAGITA, KENYA.

TF Siegert, Seattle, WA. University of Washington School of Medicine

Abstract 88

\section{Hematology and Oncology I}

Green Room (Sunset Center)

Thomas Deloughery, Presiding

3:30 REGION OF INTEREST IDENTIFICATION AND DIAGNOSTIC ACCURACY IN BREAST PATHOLOGY. DB Nagarkar, E Mercan, D Weaver, M Rendi, P Frederick, T Brunye and J Elmore, Seattle, WA; Burlington, VT and Medford, MA. University of Washington (WAFMR/WAP Student Subspecialty Award Winner)

Abstract 89

3:45 A NOVEL PEPTIDE-CONJUGATE THAT ACCUMULATES IN SARCOMA FLANK TUMORS AND PREVENTS TUMOR CELL GROWTH IN VITRO.

T Sottero, E Girard, C Correnti, M Stroud and J Olson, Seattle, WA. University of Washington

Abstract 90

4:00 DEPYROGENATED CHITOSAN AND IL-12 CURE SUPERFICIAL BLADDER CANCER IN A MURINE MODEL.

M Dopp, Loma Linda, CA. Loma Linda University

Abstract 91

4:15 DISPARITIES IN THE PRESENTATION AND TREATMENT OF NON-SMALL CELL LUNG CANCER:

A STUDY COMPARING A COUNTY FACILITY WITH A SPECIALIZED CANCER CENTER.

$S$ Lin, G In and J Nieva, Arcadia, CA. University of Southern California (WSCI Travel Award Winner)

Abstract 92

4:30 CLOSING THE GAP: ONLINE ONCOLOGY RESOURCES FOR MEDICAL STUDENTS.

$L$ Wang, T Kong, W Tran and P Ingledew, Kelowna, BC, Canada; Surrey, BC, Canada and Vancouver, BC,

Canada. University of British Columbia

Abstract 93

4:45 INVESTIGATING THE RELATIONSHIP OF BILE ACIDS AS TUMOR SUPPRESSING AGENTS IN COLORECTAL ADENOCARCINOMA.

DJ Reyes, J Trujillo, S Centuori and J Martinez, Tucson, AZ. University of Arizona

Abstract 94

5:00 HEMOGLOBINOPATHIES, DIABETES, AND AMERICAN INDIANS AND ALASKA NATIVES.

J Keane, A Hunt and E Ezeanolue, Las Vegas, NV. University of Nevada, Las Vegas

Abstract 95 


\section{Western Meeting Program}

5:15 INDICATIONS FOR POST-MASTECTOMY RADIATION (PMRT) FOLLOWING NEOADJUVANT

CHEMOTHERAPY (NAC) IN YPNO AND YPN1-3 AXILLARY NODE POSITIVE WOMEN.

B Fowble, A Jairam, A Lazar, F Wang, A Peled, L Esserman and C Park, San Francisco, CA and Sacramento, CA.

University of California, Davis School of Medicine

Abstract 96

5:30 RETROSPECTIVE STUDY OF METASTATIC MELANOMA AND RENAL CELL CARCINOMA TO THE BRAIN WITH MULTIVARIATE ANALYSIS OF PROGNOSTIC PRE-TREATMENT CLINICAL FACTORS. EA Ferrel, AT Roehrig, E Kaya, J Carlson, B Ling and A Wagner, Spokane, WA. University of Washington

Abstract 97

TEXT MESSAGING BASED INTERVENTION FOR IMPROVING RECEIPT OF SURVIVORSHIP CARE FOR ADOLESCENT AND YOUNG ADULTS (AYAS): A QUALITATIVE STUDY.

JA Bryman, A Goyal, J Casillas, F Alquaddoomi and D Estrin, Peoria, IL; Westwood, CA and New York, NY.

University of Illinois College of Medicine at Peoria

Abstract 98

Neonatal Pulmonary II

Rehearsal Room (Sunset Center)

Arlin B. Blood and Clyde Wright, Presiding

3:30 SEX-SPECIFIC PERINATAL NICOTINE EXPOSURE-INDUCED AIRWAY PHENOTYPE IN MEDIATED BY DIFFERENTIAL PKC ISOFORM EXPRESSION IN MALES AND FEMALES.

M Gong, J Liu, R Sakurai, NS Murty and VK Rehan, Torrance, CA. LA BioMed at Harbor-UCLA Medical Center

Abstract 99

3:45 INTRAUTERINE GROWTH RESTRICTION INCREASES ESTRODIAL LEVELS IN RAT LUNG.

RS Moore, C Weinheimer, Z Wang and L Joss-Moore, Salt Lake City, UT. University of Utah

Abstract 100

4:00 ANALYSIS OF NOTCH PATHWAY COMPONENTS IN LUNG INNATE IMMUNITY CELLS IN PRETERM INFANTS.

NS Bhopal, B Chan, A Fischer, D Mathur and P Minoo, Los Angeles, CA. LAC+USC Medical Center o

Children's Hospital Los Angeles

Abstract 101

4:15 INSULIN-LIKE GROWTH FACTOR-1 DOWNSTREAM SIGNALING IS DISRUPTED IN THE LUNG BY PREMATURE BIRTH AND PROLONGED MECHANICAL VENTILATION OF PREMATURE LAMBS.

C Miers, M Dahl, S Bowen, L Dong, Z Wang, D Null, B Yoder and K Albertine, Salt Lake City, UT and Davis, CA. University of Utah

Abstract 102

State-of-the-Art Speaker

DIAGNOSIS OF BPD: STRENGTHS AND LIMITATIONS.

Roberta Keller, University of California, San Francisco

A 3-DIMENSIONAL HUMAN MODEL OF BRONCHOPULMONARY DYSPLASIA DEMONSTRATES NOTCH MEDIATED PATHOPHYSIOLOGY.

J Sucre, D Wilkinson, P Vijayaraj, J Alva-Ornelas, M Paul, B Dunn and B Gomperts, Los Angeles, CA. David

Geffen School of Medicine at UCLA

Abstract 103

5:15 NASAL HIGH-FREQUENCY OSCILLATION PROVIDES ACCEPTABLE RESPIRATORY SUPPORT FOR PREMATURE LAMBS.

M Dahl, K Zuspan, S Bowen, C Bradford, L Pettet, D Null, B Yoder and K Albertine, Salt Lake City, UT and

Davis, CA. University of Utah

Abstract 104 
5:30 CHRONIC AND ACUTE HYPOXIA MARKEDLY ALTER CA2+ SIGNALING IN ADULT AND FETAL PULMONARY ARTERIAL MYOCYTES.

K Cothran, S Sandy, M Romero, A Dobyns, R Paez, M Francis, M Taylor, L Longo, C Wilson and S Wilson, Loma Linda, CA; Riverside, CA and Mobile, AL. Loma Linda University

Abstract 105

5:45 DECREASE IN INTUBATION RATES AFTER EARLY POSITIVE PRESSURE VENTILATION USING A MODIFIED NASAL CANNULA DURING NEONATAL RESUSCITATION OF LARGER PRETERM AND TERM INFANTS.

ER Wang, FB Wertheimer, R Ramanathan and M Biniwale, Los Angeles, CA. Keck School of Medicine of University of Southern California

Abstract 106

\section{Neonatology General II}

Babcock \#6 (Sunset Center)

Mariana Baserga and Rowena Cayabyab, Presiding

3:30 LIMB PROPRIOCEPTIVE STIMULATION DECREASES INTERMITTENT HYPOXIA AND BRADYCARDIA IN PREMATURE NEONATES.

K Kesavan, P Frank, P Benharash and R Harper, Los Angeles, CA. University of California, Los Angeles

Abstract 107

3:45 IN VIVO INDUCTION OF HEME OXYGENASE-1 BY ASPIRIN.

CM Konecny, S Wong, S Lu, K Fujioka, F Kalish, H Zhao, RJ Wong and DK Stevenson, Stanford, CA and La Jolla, CA. Stanford University School of Medicine

Abstract 108

4:00 LIMITING FEEDING DECREASES ALVEOLAR FORMATION IN THE LUNG OF PREMATURE LAMBS SUPPORTED BY NON-INVASIVE VENTILATION.

C Bradford, L Joss-Moore, S Hagen-Lillevik, M Dahl, L Dong, Z Wang, D Null, B Yoder and K Albertine, Salt Lake City, UT and Davis, CA. University of Utah

Abstract 109

4:15 SURGERY DURING PHASE II RETINOPATHY OF PREMATURITY (ROP) LEADS TO MORE LASER INTERVENTION.

C Torr, B Yoder and J Beachy, Salt Lake City, UT. University of Utah

Abstract 110

4:30 CORRELATION OF MRI BRAIN FINDINGS WITH SEVERITY OF NEURAL TUBE DEFECT IN PATIENTS WITH SPINA BIFIDA.

DL Heyliger and A Achiriloaie, Loma Linda, CA. Loma Linda University

Abstract 111

4:45 LOWER BONE MINERALIZATION IN PRETERM INFANTS WITH NEPHROCALCINOSIS.

S Malone Jenkins, G Chan, M Grinsell and K Weaver Lewis, Salt Lake City, UT and Murray, UT. University of Utah

Abstract 112

5:00 PREOPERATIVE AEEG ABNORMALITIES IN TERM NEONATES WITH COMPLEX CONGENITAL

HEART DISEASE.

D Goff, A Pardo, P Pegis, D Deming and A Hopper, Loma Linda, CA. Loma Linda University Children's Hospital

Abstract 113

5:15 CUMULATIVE INTRAVENOUS MACRONUTRIENT DOSE AND PARENTERAL NUTRITION

ASSOCIATED CHOLESTASIS IN PRETERM NEONATES AND NEONATES WITH GASTROINTESTINAL DISORDERS.

B Abebe, G Wegrzyn, T Grogan, M Flores and KL Calkins, Los Angeles, CA. UCLA Mattel Children’s Hospital

Abstract 114

5:30 MORTALITY AND MORBIDITIES ASSOCIATED WITH PERSISTENT PATENT DUCTUS ARTERIOSUS IN EXTREMELY LOW BIRTH WEIGHT INFANTS.

$P$ Shastry, S Vaikunth, B Siassi, S Bhombal, L Barton, R Ramanathan and R Cayabyab, Glendale, CA and Los Angeles, CA. LAC+USC Medical Center, Keck School of Medicine 


\section{Western Meeting Program}

5:45 ANTENATAL FACTORS ASSOCIATED WITH COMBINED CEREBELLAR AND INTRAVENTRICULAR HEMORRHAGE IN PRETERM NEONATES.

LK Lee, M Shiroishi, L Vachon, R Cayabyab and R Ramanathan, Los Angeles, CA. USC/CHLA

\section{Neuroscience I}

Chapman \#4 (Sunset Center)

Marie-Francoise Chesselet, Presiding

3:30 5-HT6 RECEPTORS IN THE INDIRECT BUT NOT DIRECT STRIATAL PATHWAY REGULATE COCAINE REINFORCEMENT.

A Gibson, M Brodsky and J Neumaier, Seattle, WA. University of Washington

Abstract 117

3:45 MICROGLIA ACTIVATION AND PROLIFERATION IN ISCHEMIC PRECONDITIONING.

RE Dodge and JR Weinstein, Seattle, WA. University of Washington

Abstract 118

4:00 OPTOGENETIC STUDIES OF RESPIRATORY RHYTHM GENERATION IN TRANSGENIC MICE.

BP Mosher, M Tariq, H Koizumi, N Koshiya, R Zhang and J Smith, Seattle, WA and Bethesda, MD. University of Washington

Abstract 119

4:15 C-JUN N-TERMINAL KINASE SIGNALING IN CHRONIC EPILEPSY.

$R$ Boehm, F Concepcion and N Poolos, Seattle, WA. University of Washington

Abstract 120

4:30 VALIDATION OF THE USE OF A BEHAVIORAL PAIN ASSESSMENT TOOL WITH BRAIN-INJURED ICU PATIENTS.

CG Steiner, B McNulty, R Marsh, C Gélinas and A Joffe, Seattle, WA and Montreal, QC, Canada. University of Washington

Abstract 121

4:45 ASSOCIATIONS BETWEEN SOMATOSENSORY EVOKED POTENTIALS AND CLINICAL DIAGNOSES IN MULTIPLE SCLEROSIS.

AE Kloss, Seattle, WA. University of Washington

Abstract 122

5:00 NEURAL RESPONSES DURING REFLEXIVE BLINKING ARE ABNORMAL IN BLEPHAROSPASM.

D Kelly, B Berman and E Shelton, Aurora, CO. University of Colorado Anschutz Medical Campus

Abstract 123

5:15 PROTEOLIPID PROTEIN LABELING OF EXTRACELLULAR VESICLES.

GD Fliney, D Harlow and K Saul, Aurora, CO. University of Colorado

Abstract 124

5:30 EFFECTS OF HYDROGEN PEROXIDE AND PHENYLBUTYRATE ON MITOCHONDRIAL MEMBRANE POTENTIAL IN DOPAMINE NEURON.

O Gordon, W Zhou, A D’Alessandro, T Nemkov, K Hansen and C Freed, Boulder, CO and Aurora, CO.

University of Colorado

Abstract 125

5:45 UNIQUE HYPEROXIA TOLERANT RATS ARE LESS ANXIOUS AND HAVE LARGER HIPPOCAMPI.

KA Baer, PV Wilson, N Busquet, M Mesches, K Huber, N Serkova, A Newman, K Repine, Q He, A

Fernandez-Bustamante and JE Repine, Aurora, CO. Webb-Waring Center, University of Colorado Anschutz Medical Center 
Pulmonary and Critical Care I

Studio 105 (Sunset Center)

Michael Schivo, Presiding

3:30 CHANGES IN FRAILTY ARE ASSOCIATED WITH DISABILITY AFTER LUNG TRANSPLANT.

P Shrestha, A Soong, D Huang, M Mindo, L Leard, J Golden, P Blanc, S Hays, J Kukreja and J Singer,

San Francisco, CA. University of California, San Francisco

Abstract 127

3:45 THE IMPACT OF LUNG TRANSPLANTATION ON QUALITY-ADJUSTED LIFE YEARS.

D Huang, P Shrestha, A Soong, L Leard, S Hays, J Golden, J Kukreja, P Blanc and J Singer, San Francisco, CA.

University of California

Abstract 128

4:00 LUNG TRANSPLANTATION IMPROVES HEALTH-RELATED QUALITY OF LIFE IN PATIENTS WITH ADVANCED LUNG DISEASE.

A Soong, P Shrestha, D Huang, M Mindo, L Leard, J Kukreja, P Blanc, S Hays, J Golden and J Singer,

San Francisco, CA. University of California, San Francisco

Abstract 129

4:15 INVESTIGATING THE IMPACT OF LIVING ENVIRONMENT ON PAP ADHERENCE.

HS Liou, V Kapur and M Billings, Seattle, WA. University of Washington

Abstract 130

4:30 MUSCLE ATROPHY AND CLINICAL OUTCOMES IN CRITICALLY ILL PATIENTS.

A Lin, L Gonzalez-Cuyar, A Bunnell and C Hough, Seattle, WA. University of Washington

Abstract 131

4:45 EFFECTS OF ULTRASOUND TRAINING DURING YEAR-2 OF MEDICAL SCHOOL ON YEAR-3

MEDICAL STUDENTS.

R Krause, R Krause, C Krause and V Dinh, Loma Linda, CA. Loma Linda University

Abstract 132

5:00 EFFECTIVENESS OF ANIMATED SIMULATION FOR TEACHING ULTRASOUND TO MEDICAL STUDENTS.

V Dinh, J Avila, MS Douglas, R Krause and D Sheldon, Redlands, CA and Lexington, KY. Loma Linda University

School of Medicine

Abstract 133

5:15 EFFECTS OF STUDENT-PERFORMED POINT-OF-CARE ULTRASOUND ON PHYSICIAN DIAGNOSIS AND MANAGEMENT IN THE EMERGENCY DEPARTMENT.

AJ Sumnicht, D Udrea, L Villarreal, D Lo, S Gondra-Sanabria, R Chyan and V Dinh, Loma Linda, CA. Loma Linda University

Abstract 134

5:30 MEDICAL STUDENT-PERFORMED POINT-OF-CARE ULTRASOUND: THE EFFECT ON PATIENT SATISFACTION IN THE EMERGENCY DEPARTMENT.

D Lo, L Villarreal, AJ Sumnicht, S Gondra-Sanabria, D Udrea, R Chyan and V Dinh, Cherry Valley, CA. Loma Linda University

Abstract 135

5:45 CONCURRENT BIRT-HOGG-DUBÉ SYNDROME AND SARCOIDOSIS.

BT Kuhn and R Harper, Sacramento, CA. University of California, Davis Medical Center (WAFMR Scholar Awardee)

Abstract 136 
Surgery I

Bingham Room \#3 (Sunset Center)

Subhas Gupta and Lee Pu, Presiding

3:30 ASSESSMENT OF A NOVEL, PORTABLE, TABLET-BASED SCANNER FOR THE THREE-DIMENSIONAL IMAGING OF THE FACE.

L Kim, P Lewis and S Gupta, Redlands, CA. Loma Linda School of Medicine

Abstract 137

3:45 CROWDSOURCING FOR PATIENT-REPORTED OUTCOMES AFTER BREAST RECONSTRUCTION: A NOVEL TOOL FOR UNDERSTANDING THE PATIENT EXPERIENCE.

Y Lin, CV Vu and S Gupta, Loma Linda, CA. Loma Linda University (WAFMR/WAP Student Subspecialty Award Winner)

Abstract 138

4:00 ADIPOSE DERIVED HUMAN MESENCHYMAL STEM CELL INJECTIONS IMPROVE ACHILLES TENDON HEALING IN A RAT MODEL.

SK Devana, O McBride, C Eliasberg, T Kowalski, S Park, F Petrigliano and N Soohoo, Los Angeles, CA. David Geffen School of Medicine at UCLA

Abstract 139

4:15 ANTERIOR CLOSING WEDGE PROXIMAL TIBIA OSTEOTOMY TO REDUCE ANTERIOR CRUCIATE LIGAMENT FORCE AND KNEE INSTABILITY.

J Mathew, D Boguszewski, E Cheung, K Yamaguchi, K Markolf, D McAllister and F Petrigliano, Los Angeles, CA. David Geffen School of Medicine at UCLA

Abstract 140

4:30 A RETROSPECTIVE AUDIT OF THE TREATMENT AND RECOVERY OF BREAST CANCER PATIENTS: BUILDING A PRELIMINARY BUNDLED PAYMENT MODEL FOR BREAST CANCER.

Y Lin and S Gupta, Yorba Linda, CA. Loma Linda University School of Medicine

Abstract 141

4:45 ENDOSCOPIC AND OPEN VEIN HARVESTING TECHNIQUES PRODUCED SIMILAR VEIN QUALITY AND MAJOR ADVERSE CARDIAC EVENTS AT 5 YEAR FOLLOW-UP.

$B$ Santi, J Chen, J Wu, M Chen, L Uhr and J Lee, Santa Clara, CA; Honolulu, HI and Boston, MA. Santa Clara University

Abstract 142

5:00 STEPPING OUT OF THE SHADOW: INVESTIGATING A TEACHER-LEARNER CONTRACT FOR OBSERVERSHIPS IN THE CLINICAL SETTING.

K D’Souza, D Cojocaru, V Ye, D Duffy, G Warnock and G Blair, Vancouver, BC, Canada. University of British Columbia

Abstract 143

5:15 PATIENT SPECIFIC 3D PRINT MODELS IMPROVE DEFORMITY CORRECTION AFTER PROXIMAL FEMORAL OSTEOTOMY FOR SLIPPED CAPITAL FEMORAL EPIPHYSIS.

L Cherkasskiy, JP Caffrey, AF Szewczyk, E Cory, JD Bomar, C Farnsworth, M Jeffords, RL Sah and VV Upasani, La Jolla, CA and San Diego, CA. University of California San Diego

Abstract 144

5:30 WRIST MOTION VARIATION BETWEEN NOVICES AND EXPERIENCED SURGEONS PERFORMING SIMULATED AIRWAY SURGERY.

EJ Callahan, R Bly, K Moe, K Johnson, N Aghdasi, I Bohannon, B Hannaford and MG Sardesai, Kirkland, WA and Seattle, WA. University of Washington

Abstract 145

5:45 FABRICATIONS IN THE FOUNTAIN OF YOUTH: EVALUATION OF COLLAGEN INDUCTION CLAIMS IN PRODUCT ADVERTISING.

C Johnson and S Gupta, Loma Linda, CA. Loma Linda University

Abstract 146 
WELCOME RECEPTION AND POSTER SESSION

Jointly sponsored by

\section{WESTERN SECTION AMERICAN FEDERATION FOR MEDICAL RESEARCH \\ WESTERN SOCIETY FOR CLINICAL INVESTIGATION \\ WESTERN ASSOCIATION OF PHYSICIANS \\ WESTERN SOCIETY FOR PEDIATRIC RESEARCH \\ WESTERN STUDENT MEDICAL RESEARCH FORUM \\ Carmel Mission Inn - Carmelo Ballroom \\ Thursday, January 28, 2016 \\ 6:00 PM - 7:30 PM}

(Presenters in attendance at their posters from 6:15 - 7:15 pm)

Shuttle service from Sunset Center to Carmel Mission Inn provided

Adolescent Medicine and General Pediatrics

Cardiovascular

Community Health

Endocrinology and Metabolism

General Internal Medicine and Aging

Health Care Research

Hematology and Oncology

Infectious Diseases

Neonatal Pulmonary

Neonatology General

Pulmonary \& Critical Care Adult

Surgery

\section{Poster}

Number

\section{Adolescent Medicine and General Pediatrics}

1 COMMUNITY HEALTH ASSESSMENT OF INFANTS IN RURAL INDIA.

A Allen, C Orlando, D Shapiro, M Parkinson and B Fassl, Salt Lake City, UT. University of Utah School of Medicine

JD Tran, CH Lee, CT Pham, MD Nava and B Afghani, Irvine, CA. University of California, Irvine School of Medicine

\section{Cardiovascular}

MR Carrillo, Y Bade, M Garneni, A Shaik, O Cristian, A Joshi, E Kong and B Afghani, Irvine, CA; Huntington

Beach, CA and Orange, CA. Creighton University 
USE OF MEDICAL MARIJUANA FOR TREATMENT OF PEDIATRIC PATIENTS WITH EPILEPSY. MR Carrillo, GE Jennings, C Le, A Dong, D Devineni, R Sahafi, H Goo and B Afghani, Huntington Beach, CA; Irvine, CA and Orange, CA. Creighton University

Abstract 150 K Lam, M Dharmar and S Berger, Sacramento, CA and Sacramento, CA. University of California, Davis School of Medicine

Abstract 151

LEFT VENTRICULAR SHAPE VARIATION IN PATIENTS WITH AORTIC COARCTATION PRE- AND POST-STENT IMPLANTATION.

A Ortiz, A Suinesiaputra, A Young, G Farrar, B Printz, H El-Said, J Moore, J Omens, A McCulloch, J Perry and S Hegde, Auckland, New Zealand; San Diego, CA and La Jolla, CA. University of California, San Diego

\section{Community Health}

CREATE CULTURALLY APPROPRIATE CERVICAL CANCER INFORAMTIONAL MATERIAL TO DISTRIBUTE DURING CERVICAL SCREENINGS AND COMMUNITY OUTREACH EVENTS AT THE UGANDA CANCER INSTITUTE.

D Borin, Seattle, WA and Kampala, Uganda. University of Washington

Abstract 153

DILLON, MONTANA: SEXUAL EDUCATION ADVANCEMENT.

N Broden, Great Falls, MT. University of Washington

Abstract 154

EVALUATING THE CHALLENGES OF INTEGRATING HEALTH EDUCATION INTO A SCHOOL CURRICULUM IN RURAL INDIA.

B Cheung, K Shih, B Smith, M Smith, S Browne and D Raff, Burnaby, BC, Canada. University of British Columbia

PREVENTING CHILDHOOD OBESITY ON PRINCE OF WALES ISLAND: IDENTIFICATION OF BARRIERS THAT HINDER HEALTHY LIFESTYLES AT HOME AND TARGETING PARENTS IN OBESITY PREVENTION EFFORTS.

BD Dahms, Seattle, WA. University of Washington School of Medicine

Abstract 156

LM Daudt, Seattle, WA. University of Washington

THE FIVE-YEAR CUMULATIVE INCIDENCE OF BURNS IN UGANDA: EARLY OUTCOMES OF A CROSS-SECTIONAL HOUSEHOLD SURVEY.

AS Maccan, A Ribeiro, M Caulfield, A Rajwani, J Huebner, M Ario, P Laker, J Siever, MM Ajiko, N O’Hara and R Evans, Chilliwack, BC, Canada; Soroti, Uganda and Vancouver, BC, Canada. University of British Columbia J Maddox, W Kopp, B Fassl, A Sherpa and D Levy, Salt Lake City, UT and Forest Knolls, CA. University of Utah School of Medicine 
15 DANCING YOUR WEIGHT OFF: AN INTERACTIVE HIGH SCHOOL PEER EDUCATION PROJECT TO ASSESS AND INCREASE ADOLESCENT AWARENESS OF THE IMPORTANCE OF EXERCISE.

J Martin, M Castaneda, L Arreola, A Calderon and R Kinman, Fresno, CA and Madera, CA. Fresno High School

Abstract 161

DON'T LET BUTTE BURN!

H Paladichuk, Seattle, WA. University of Washington School of Medicine

Abstract 162

ASSESSING THE EFFECTIVENESS OF A CHILD MALNUTRITION TREATMENT CENTER IN RURAL INDIA.

M Parkinson, A Allen, C Orlando, D Shapiro and B Fassl, Salt Lake City, UT. University of Utah

Abstract 163

INCREASING UP-TO-DATE VACCINATION STATUS AMONG CHILDREN ENROLLED IN THE WIC PROGRAM IN ELLENSBURG, WASHINGTON.

CM Shae, Wenatchee, WA. University of Washington School of Medicine

SUMMER NUTRITION CHALLENGE: ENCOURAGING HEALTHY EATING BITE BY BITE IN ODESSA, WASHINGTON.

A Snyder, Seattle, WA. University of Washington

Abstract 165

THE SHOSHONE BICYCLE HELMET PROJECT: INCREASING HELMET USE THROUGH DISTRIBUTION OF FREE HELMETS AND BILINGUAL EDUCATIONAL MATERIALS.

ND Swenson, Seattle, WA. University of Washington

Abstract 166

IMPROVING STROKE AWARENESS IN URBAN AND RURAL PERU THROUGH A HOSPITAL-BASED STROKE PREVENTION CAMPAIGN.

MV Tulloch-Palomino, Shoreline, WA. University of Washington School of Medicine

\section{Endocrinology and Metabolism}

23 PARATHYROID CARCINOMA A SMOLDERING DISEASE: CASE REPORTS.

DV Byreddy, D Schade, MR Burge, P Kapsner and M Bouchonville, Albuquerque, NM. University of New Mexico

PRIMARY CARE PROVIDERS' PERCEPTIONS OF LIFESTYLE MODIFICATION AND MANAGEMENT FOR OBESITY AND PREDIABETES.

$S$ Tsoi, E Vasti and T Moin, Los Angeles, CA and San Francisco, CA. David Geffen School of Medicine at UCLA

General Internal Medicine and Aging 
27 BEHAVIORAL PHENOTYPE IN CHILDREN WITH PRADER-WILLI SYNDROME.

N Alsaleh, P Gupta and J Pula, Stanford, CA and Paterson, NJ. Stanford University School of Medicine

Abstract 173

PRADER-WILLI SYNDROME DUE TO AN UNBALANCED DE NOVO TRANSLOCATION T(15;19)(Q12; P13.3).

V Dang, A Surampalli, SH Youn, J Gold and V Kimonis, Irvine, CA and Loma Linda, CA. University of California, Irvine

Abstract 174

29 IS INCIDENTAL FINDING THE BEST TERM? A STUDY OF PATIENTS' PERSPECTIVES.

$N$ Tan, L Amendola, MJ Horike-Pyne, FM Hisama, W Burke, B Wilfond and G Jarvik, Seattle, WA. University of Washington

Abstract 175

30 SCOLIOSIS IN A PRADER-WILLI SYNDROME CLINIC.

D Viskochil and D Mason, Salt Lake City, UT. University of Utah

Abstract 176

\section{Health Care Research}

31 DO ASK, DO TELL: AN INTERACTIVE WEB-BASED ASSESSMENT OF PHYSICIAN WELLNESS.

D Cojocaru, E Skarsgard, C Strahlendorf, FK Kozak, P Sneddon, D Duffy, N O'Hara and T Newlove, Vancouver, BC, Canada. University of British Columbia - Children's Hospital

Abstract 177

STUDENTS AS FUTURE EDUCATIONAL LEADERS IN THE DEVELOPMENT OF LEARNING RESOURCES: AN UNDERGRADUATE SURGICAL CURRICULUM INITIATIVE.

D Cojocaru, K D'Souza, D Duffy and G Blair, Vancouver, BC, Canada. University of British Columbia

Abstract 178

STAYING ALIVE: ACTIVE SHOOTER SIMULATION IN THE OPERATING ROOM.

AJ Czynski, V Layel, TK Denmark, M Vadi, E Ghazal, MY Woodfin, M Malkin, J Lenart and J Cristall, Redlands, CA and Loma Linda, CA. Loma Linda University

Abstract 179

ATTITUDES OF GLOBAL HEALTH PROFESSIONAL FACULTY TO SOCIAL MEDIA AS A TEACHING TOOL.

K D’Souza, L Henningham, R Zou, J Huang, L O’Sullivan, J Last and K Ho, Vancouver, BC, Canada; Melbourne, VIC, Australia; Shanghai, China; Birmingham, United Kingdom and Dublin, Ireland. University of British Columbia

Abstract 180

THE OPTIMAL ATTRIBUTES OF A TRAUMA TEAM LEADER: EVIDENCE FROM A DISCRETE CHOICE EXPERIMENT.

D Mo, N O'Hara, R Hengel and A Singhal, Vancouver, BC, Canada. University of British Columbia

Abstract 181

A Rajwani, J Huebner, MD Caulfield, A Ribeiro, AS Maccan, MM Ajiko, N O'Hara and R Evans, Vancouver, BC, Canada and Soroti, Uganda. University of British Columbia 
37 SOCIAL MEDIA USE IN EMERGENCY ULTRASOUND FELLOWSHIP EDUCATION.

$J$ Wang, R Amini and S Adhikari, Tucson, AZ. University of Arizona

38 EVALUATION OF MATERNAL AND INFANT PRACTICES AND ILLNESS IN RURAL NEPAL.

$K$ Wolpert, S Ryan, B Fassl and D Levy, Salt Lake City, UT. University of Utah

Abstract 184

\section{Hematology and Oncology}

THE EFFECT OF DOT1L INHIBITION ON RNA POLYMERASE II PAUSING.

$R$ Ancar, T Neff and K Bernt, Parker, CO. University of Colorado School of Medicine

Abstract 185

EFFECT OF SURVIVIN AND CANCER CELL-DERIVED EXOSOMES ON NATURAL KILLER CELL CYTOTOXICITY.

D Chi, H Ferguson, L Oppegard and N Wall, Loma Linda, CA. Loma Linda University

Abstract 186

41 AUTOIMMUNE HEMOLYTIC ANEMIA AND THE SEQUELA OF IGA LINEAR DERMATITIS.

TV Desai, Las Vegas, NV. University of Nevada School of Medicine

Abstract 187

MICRODOSIMETRIC EVALUATION OF PROTON ENERGY DISTRIBUTIONS IN THE VICINITY OF METAL IMPLANTS.

S Heczko, G McAuley, J Slater and A Wroe, South Pasadena, CA and Loma Linda, CA. Loma Linda University Abstract 188

GENE-ULTRAVIOLET RADIATION INTERACTIONS DETERMINING MELANOMA RISK PHENOTYPES. DD Lynn, Aurora, CO. University of Colorado Denver

EVALUATION OF A DUAL FOCUSING MAGNET SYSTEM FOR TREATMENT OF SMALL PROTON TARGETS.

TT Nguyen, S Heczko, G McAuley, J Slater, J Slater and A Wroe, Loma Linda, CA. Loma Linda University

SUCCESSFUL TREATMENT OF ACUTE RENAL FAILURE IN PATIENT WITH ACTIVE LUPUS NEPHRITIS AND ATYPICAL HEMOLYTIC UREMIC SYNDROME WITH C5A INHIBITOR, ECULIZUMAB.

S Sarkissian, Panorama City, CA. University of California, Irvine

HEMOPHAGOCYTIC LYMPHOHISTIOCYTOSIS COMPLICATING AN UNUSUAL CASE OF CD16+ EXTRANODAL NK LYMPHOMA, NASAL TYPE WITH BONE MARROW AND CENTRAL NERVOUS SYSTEM INVOLVEMENT.

S Sarkissian and P Siaghani, Panorama City, CA and Orange, CA. University of California, Irvine

A RARE CASE OF EBV NEGATIVE T-CELL POST RENAL TRANSPLANT LYMPHOPROLIFERATIVE DISORDER.

S Sarkissian and A Nael Amzajerdi, Panorama City, CA and Orange, CA. University of California, Irvine 
ATYPICAL PRESENTATION OF LOW-GRADE FIBROMYXOID SARCOMA IN THE ANTERIOR MEDIASTINUM IN A 73 YEAR OLD FEMALE.

VM Williams, M Herrmann and AVega, Loma Linda, CA and Los Angeles, CA. Loma Linda University

Abstract 195

FATAL SICKLE CELL CRISIS DUE TO CANDIDA ALBICANS INFECTION IN A CHILD.

K Young, A Miller, K Boayue and H Agarwal, Tucson, AZ and Albuquerque, NM. The University of Arizona

ROLE OF TRANSFORMING GROWTH FACTOR-BETA IN MEDIATING INFLAMMATION AND ANGIOGENESIS IN SMAD4 DEFICIENT HEAD AND NECK SQUAMOUS CELL CARCINOMAS. $J$ Yu, A Hernandez and X Wang, Aurora, CO. University of Colorado Denver

CHANGES IN EXPRESSION OF METABOLIC GENES IN IMMORTALIZED MOUSE EMBRYONIC FIBROBLAST CELLS IMPACT GROWTH AND FITNESS.

A Yufa, J Lay, A Chang, N Balanis, A Minasyan, N Graham and T Graeber, Riverside, CA. University of California, Los Angeles

\section{Infectious Diseases}

GROUP A STREP: STILL A THREAT THREE PRESENTATIONS OF INVASIVE GROUP A $\beta$-HEMOLYTIC STREPTOCOCCUS.

N Neal, SU Das and P Patamasucon, Las Vegas, NV. University of Nevada School of Medicine

M Dahl, C Veneroni, K Zuspan, A Lavizzari, S Bowen, D Null, B Yoder, K Albertine and R Dellaca', Salt Lake City, UT; Milan, Italy and Davis, CA. University of Utah WITH HYPOXIC-ISCHEMIC ENCEPHALOPATHY IN THE UNITED STATES 1997-2012.

CA Burkhead, A Song, A Lakshmanan, E Ho, P Friedlich and C McLean, Arcadia, CA and Los Angeles, CA. Children's Hospital of Los Angeles LIFE FOR LOW INCOME FAMILIES AFTER NEONATAL INTENSIVE CARE UNIT DISCHARGE.

N Flores, PS Friedlich, MB Belfort, DL Vanderbilt, R Williams, MD Kipke and A Lakshmanan, Los Angeles, CA and Boston, MA. Children's Hospital Los Angeles 

OVER A 5-YEAR PERIOD.

N Kraus, B Becerra, RD Clark and S Ramanathan, Loma Linda, CA. Loma Linda University

61 RESOURCE UTILIZATION FOR NEONATES WITH TRISOMY 18 IN CALIFORNIA.

NG Lynch, J hu, PS Friedlich and A Lakshmanan, Los Angeles, CA. Children's Hospital Los Angeles and LAC +USC Medical Center, Keck School of Medicine, University of Southern California

RESOURCE UTILIZATION FOR NEONATES WITH TRISOMY 13 IN CALIFORNIA.

NG Lynch, J hu, PS Friedlich and A Lakshmanan, Los Angeles, CA. Children's Hospital Los Angeles and LAC + USC Medical Center, Keck School of Medicine of University of Southern California

NICU FELLOWSHIPS PROVIDE LESS ACCESS AND TRAINING IN POINT-OF-CARE ULTRASONOGRAPHY THAN PICU TRAINING PROGRAMS.

JT Nguyen, R Amirnovin, R Ramanathan and S Noori, Los Angeles, CA. Keck School of Medicine of University of Southern California; Children's Hospital Los Angeles

Abstract 209

\section{Pulmonary \& Critical Care Adult}

UTILIZING A MULTIMODAL APPROACH IN TEACHING MEDICAL STUDENTS ULTRASOUNDGUIDED PROCEDURES.

C Krause, R Krause and V Dinh, Loma Linda, CA. Loma Linda University

66 A CASE OF URTICARIA THAT RESULTED IN A BROKEN HEART.

N Qamar, S Teuber and S Mateev, Sacramento, CA and Mather, CA. University of California, Davis Health System

\section{Surgery} SYNECHIAE FOLLOWING FUNCTIONAL ENDOSCOPIC SINUS SURGERY: A RETROSPECTIVE REVIEW.

A Amanian, J Manji, A Habib, S Alsaleh and A Javer, Vancouver, BC, Canada. University of British Columbia 
70 A RETROSPECTIVE REVIEW OF TEMPOROMANDIBULAR JOINT RECONSTRUCTION WITH AUTOGENOUS COSTOCHONDRAL ARTHROPLASTY.

F Chan and DJ Courtemanche, Vancouver, BC, Canada. University of British Columbia

Abstract 216

71 ROBOTIC SIMULATOR SKILLS: IMPACT OF DIFFERENT BACKGROUND AUDITORY ENVIRONMENTS ON LEARNING CURVE OF NOVICE SURGEONS.

BS Chung, AL Wong, A Erskine, AR Kutzner, C Ritchie, P Yang, J Shen, S Abourbih and D Baldwin, Redlands, CA. Loma Linda University School of Medicine

Abstract 217

ENHANCING THE QUALITY OF THE CHILD AND FAMILY SURGICAL EXPERIENCE WITH

TELEHEALTH.

P Dean, M O'Donnell and E Skarsgard, Vancouver, BC, Canada. University of British Columbia

Abstract 218

DETECTION OF ABNORMALLY SHAPED EARS IN NEWBORNS.

$D$ Lu, J Pauwels, C Jin, FK Kozak and N Chadha, Delta, BC, Canada and Vancouver, BC, Canada. British

Columbia Children's Hospital

Abstract 219

EMOTIONAL CONCERNS IN SURGICAL CANCER SURVIVORS NOT TREATED WITH CHEMOTHERAPY

T Nikoomanesh and M Goldfarb, Pomona, CA and Santa Monica, CA. Western University of Health Sciences

Abstract 220

THE EFFECT OF LASER FIBER STRIPPING ON FRAGMENTATION OF URINARY TRACT CALCULI.

C Ritchie, P Yang, B Peplinski, M Keheila, S Cheriyan, S Abourbih and D Baldwin, Loma Linda, CA. Loma Linda University

Abstract 221

EFFECTIVE NON-OPERATIVE MANAGEMENT OF SEVERE BLUNT LIVER TRAUMA.

C Slattery, S Aarabi, H Foy and G O'Keefe, Seattle, WA. University of Washington

Abstract 222

FRAILTY PREDICTS POSTOPERATIVE MORBIDITY/MORTALITY AFTER COLECTOMY FOR C-DIFFICILE COLITIS.

E Telemi, R Venkat and O Trofymenko, Tucson, AZ. University of Arizona

Abstract 223

FRAILTY IS A PREDICTOR OF POSTOPERATIVE MORBIDITY AND MORTALITY AFTER COLECTOMY FOR CANCER.

O Trofymenko, R Venkat, E Telemi and V Nfonsam, Tucson, AZ. University of Arizona College of Medicine -

Tucson

Abstract 224 
JOINT PLENARY SESSION

DISEASES WITHOUT BORDERS

\author{
WESTERN SECTION AMERICAN FEDERATION FOR MEDICAL RESEARCH \\ WESTERN SOCIETY FOR CLINICAL INVESTIGATION \\ WESTERN ASSOCIATION OF PHYSICIANS \\ WESTERN SOCIETY FOR PEDIATRIC RESEARCH \\ WESTERN STUDENT MEDICAL RESEARCH FORUM \\ Sunset Center Theater \\ Friday, January 29, 2016 \\ 8:00 AM - 11:40 AM
}

Paul Rozance and Kristina Utzschneider, Presiding

8:00 WSPR ABBOTT NUTRITION LOWELL GLASGOW STUDENT RESEARCH AWARD

DEFAULT MODE NETWORK ACTIVITY: TESTING FOR ASSOCIATION WITH EXTERNALIZING

BEHAVIOR PROBLEMS WITH AND WITHOUT CALLOUS UNEMOTIONAL TRAITS.

$B C$ Walsh, M Dalwani and J Sakai, Northglenn, CO. University of Colorado School of Medicine

Abstract 226

8:15 WSPR ABBOTT NUTRITION DAVID W. SMITH PEDIATRIC TRAINEE RESEARCH AWARD INFLAMMATORY PROSTAGLANDIN E2 INHIBITS OLIGODENDROCYTE PROGENITOR CELL MATURATION: MECHANISM FOR NEONATAL WHITE MATTER INJURY.

L Shiow and D Rowitch, San Francisco, CA. University of California, San Francisco

8:30 E.E. OSGOOD AWARD

CALCIUM RELEASE PATTERNS IN MOUSE ATRIAL CARDIOMYOCYTES: ROLE OF TRANSVERSEAXIAL TUBULES.

X Yue, R Zhang, B Kim, A Ma, JI Goldhaber and KD Philipson, Los Angeles, CA and Xi'an, China. Cedars Sinai Medical Center

8:45 WAFMR OUTSTANDING INVESTIGATOR AWARD

IDENTIFICATION OF A NOVEL INNATE IMMUNE SIGNALING FACTOR, TNK1, THAT REGULATES VIRAL INFECTION.

T Saito, Los Angeles, CA. University of Southern California

9:00 WSPR ABBOTT NUTRITION YOUNG INVESTIGATOR RESEARCH AWARD

BASIC SCIENCE FOR BABY BRAINS: TRANSLATIONAL INVESTIGATIONS OF NEURAL REPAIR

Lauren Jantzie, University of New Mexico

$$
\text { 9:30 - 9:45 am Intermission }
$$

W. Conrad Liles and Frederick Buckner, Presiding

9:45 WSPR STANLEY WRIGHT MEMORIAL LECTURE

SOLVING THE PUZZLE OF PRETERM BIRTH: CALENDAR EVENT OR IMMUNOLOGIC ANOMALY.

David K. Stevenson, Stanford University

10:15 WSPR JOSEPH W. ST. GEME, JR. EDUCATION AWARD

Presenter: Robin Ohls, University of New Mexico

Recipient: Carol Clericuzio, University of New Mexico 
10:25 WAP DISTINGUISHED LECTURESHIP

EBOLA: LESSONS LEARNED.

Michele Barry, Stanford University School of Medicine

10:55 WSCI OUTSTANDING INVESTIGATOR AWARD

MOLECULAR LANDSCAPE IN COLORECTAL CANCER

Heinz-Josef Lenz, University of Southern California, Keck School of Medicine

11:25 WSCI MAYO SOLEY AWARD

Presenter: Frederick S. Buckner, University of Washington

Recipient: Wesley C. Van Voorhis, University of Washington

11:40 ADJOURN

11:40 WSPR Business Meeting

11:40 WSCI Business Meeting 
MEET THE MENTORS: LUNCH WITH CARMEL RESEARCH PRIZE RECIPIENTS

Panel Discussion

Friday, January 29, 2016

11:15 AM - 12:15 PM

(Intended for Students and Residents)

Cinnamon S. Bloss, PhD, University of California San Diego Henry Lee, MD, Stanford University

Melanie Cree Green, MD, PhD, University of Colorado School of Medicine Jose R Suarez, MD, MPH, PhD, University of California San Diego

(Additional charge of $\$ 10$ and lunch will be provided, limited availability: 45)

Sunset Center - Studio 105

INVESTIGATOR WORKSHOP

Friday, January 29, 2016

11:40 AM - 12:30 PM

The American Federation for Medical Research and the Tri-Societies are pleased to sponsor a workshop for Fellows and Junior Faculty. Additional charge of $\$ 10$ and lunch will be provided.

HOW TO PICK A GOOD SCIENTIFIC QUESTION

W. Conrad Liles, University of Washington

Sunset Center - Green Room

CONCURRENT SESSIONS

Friday, January 29, 2016

12:30 PM - 2:30 PM

Jointly sponsored by

WESTERN SECTION AMERICAN FEDERATION FOR MEDICAL RESEARCH

WESTERN SOCIETY FOR CLINICAL INVESTIGATION

WESTERN ASSOCIATION OF PHYSICIANS

WESTERN SOCIETY FOR PEDIATRIC RESEARCH

WESTERN STUDENT MEDICAL RESEARCH FORUM

Adolescent Medicine and General Pediatrics II . . . . . . . . . . . . . . . . . . . . . . 105

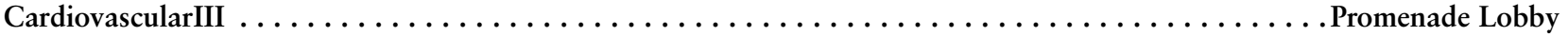

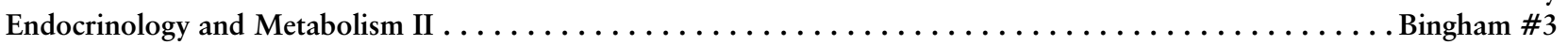

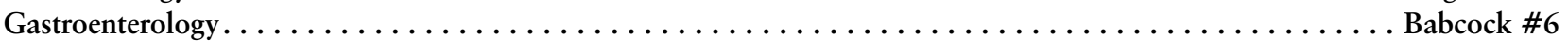

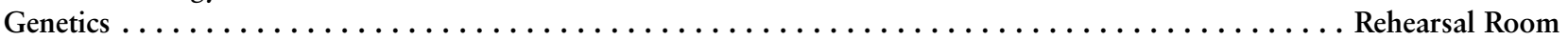

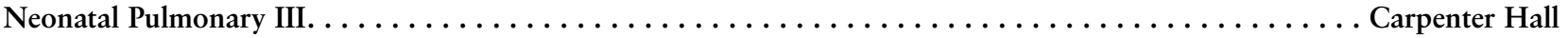

Neonatology General III . . . . . . . . . . . . . . . . . . . . . . . . All Saints Church, Seccombe Hall

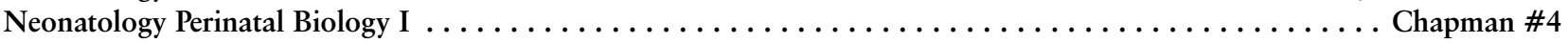

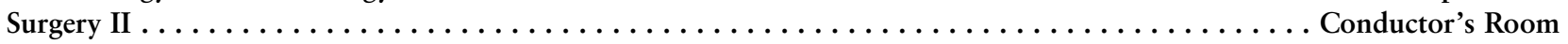

Adolescent Medicine and General Pediatrics II

Studio 105 (Sunset Center)

Samrat U. Das and Mary Ramos, Presiding

12:30 A 24 WEEK PHYSICAL FITNESS PROGRAM IMPROVES BODY COMPOSITION AMONG SOUTHWESTERN NATIVE AMERICAN ADOLESCENTS AT RISK FOR DIABETES.

L Colip, M Chavez, P Sandy, D Ghahate, J Bobelu, MR Burge and V Shah, Albuquerque, NM. University of New Mexico Health Science Center (WSPR Mead Johnson Travel Award Winner)

Abstract 230 
12:45 RELIABILITY \& VALIDITY OF THE CHISPA: A NEW BRIEF ASSESSMENT TOOL FOR ADOLESCENT SUBSTANCE USE.

D Rosero, M Ramos, T Condon and T Warner, Albuquerque, NM. University of New Mexico

1:00 ARTHROGRYPOSIS: LONG-TERM QUALITY OF LIFE ANALYSIS.

H Nouraei, B Sawatzky and J Hall, Vancouver, BC, Canada. University of British Columbia

Abstract 232

1:15 POLYMORPHIC VENTRICULAR TACHYCARDIA (PMVT) IN AN ADOLESCENT AFTER USE OF SYNTHETIC CANNABIS: UNMASKED LONG QT SYNDROME.

BH Hammond and EA Greene, Albuquerque, NM. University of New Mexico

Abstract 233

State-of-the-Art Speaker

HEALTH RELATED QUALITY OF LIFE DURING CANCER TREATMENT: PERSPECTIVES OF ADOLESCENT CANCER SURVIVORS AND THEIR CAREGIVERS.

Shiraz I. Mishra, University of New Mexico School of Medicine

PILOT STUDY ASSESSING CORRELATION OF CCL2 LEVELS, BIOMARKERS AND MODIFIABLE BEHAVIORS IN OVERWEIGHT/OBESE ADOLESCENTS.

A Dye, P Pomo, M Bodo, E Yakes Jimenez, R Orlando and A Kong, Albuquerque, NM. University of New Mexico School of Medicine

Abstract 234

2:15 CAPTURING THE SUBSTANCE USE KNOWLEDGE, ATTITUDES AND PRACTICES OF NEW MEXICO'S SCHOOL-BASED HEALTH CENTER WORKFORCE.

M Murphy, R Sebastian, T Condon and M Ramos, Albuquerque, NM. University of New Mexico

Abstract 235

Cardiovascular III

Promenade Lobby (Sunset Center)

Robert S. Ross and Carlin Long, Presiding

12:30 THE IMPACT OF SEED VARIATION ON THE MEASURED ACCURACY OF MACHINE LEARNING ALGORITHMS (AUC) FOR SEVERAL COMMON MODEL VALIDATION TECHNIQUES IN NUCLEAR MEDICINE.

VR Singh and P Slomka, Los Angeles, CA. Cedars Sinai Medical Center

Abstract 236

12:45 TEENAGERS AND ADULTS LIVING WITH CONGENITAL HEART DISEASE ARE BEING LOST TO FOLLOW UP: EVIDENCE FROM TETRALOGY OF FALLOT IN A DIVERSE PATIENT POPULATION. $S$ Behan, J Andrews and S Klewer, Tucson, AZ. University of Arizona

1:00 $\boldsymbol{\alpha}$-MYOSIN HEAVY CHAIN IN HEART FAILURE IS REDUCED IN A MINOR SUB-POPULATION OF RABBIT MYOCYTES EXPRESSING HETERODIMERIC AB ISOFORMS.

K Jaradeh, J Sharma, J Avila, KS Chavez, A Wong, T Wood, J Southard, L Mendoza, W Ferrier, J Bossuyt, K Ginsburg and J Lopez, Davis, CA. University of California, Davis

1:15 REDUCED CARDIOMYOCYTE SIZE DOES NOT ACCOUNT FOR REDUCED CARDIAC WEIGHT IN GROWTH RESTRICTED FETUSES.

D Kamna, LD Brown and S Jonker, Portland, OR and Aurora, CO. Oregon Health and Science University

1:30 TIER 1: ECMO SHOULD NOT BE TIER 1 FOR HEART TRANSPLANTATION DUE TO HIGH MORTALITY.

M Luu, T Aintablian, M Hamilton and JA Kobashigawa, Los Angeles, CA. Cedars-Sinai Medical Center 
1:45 OUTCOME OF HYPERTENSIVE HEART TRANSPLANT PATIENTS.

$R$ Sharoff, T Aintablian, G Rodriguez, M Hamilton and JA Kobashigawa, Los Angeles, CA. Cedars-Sinai Medical Center

Abstract 242

2:00 TRANS-CATHETER CLOSURE OF PATENT DUCTUS ARTERIOSUS IN SEVERELY PREMATURE

NEONATES: IS POST-LIGATION SYNDROME AN ISSUE?

D Peck, R Garg, A Phillips, M McRae, P Nevin, K Basacker, C Simmons and E Zahn, Los Angeles, CA. David

Geffen School of Medicine at UCLA

Endocrinology and Metabolism II

Bingham Room \#3 (Sunset Center)

Kristina M. Utzschneider and Taylor Soderborg, Presiding

$12: 30$

State-of-the-Art Speaker

DIABETES WITHOUT BORDERS.

Latha Palaniappan, Stanford University

1:00 $\quad$ EFFECT OF OBESITY AND CKD ON INSULIN SENSITIVITY INDICES.

I Ahmad, L Zelnick and IH DeBoer, Seattle, WA. University of Washington

Abstract 244

1:15 DIABETIC KETOACIDOSIS IN TYPE 2 VS. TYPE 1 DIABETES.

JM Miles, A Accurso, J Isautier, AE Marquez, G Wilson, K Herrmann and Y Kudva, Rochester, MN. Mayo Clinic

Abstract 245

1:30 EXERCISE INTERVENTION IMPROVES THE METABOLIC PROFILE OF SOUTHWESTERN NATIVE AMERICAN ADOLESCENTS.

L Colip, M Chavez, P Sandy, D Ghahate, J Bobelu, V Shah and MR Burge, Albuquerque, NM. University of New Mexico

Abstract 246

1:45 CAN THE DAWN PHENOMENON BE PREDICTED IN ORDER TO PROGRAM AN INSULIN PUMP?

L Ereifej, M Bouchonville, E Duran-Valdez and D Schade, Albuquerque, NM. University of New Mexico

Abstract 247

2:00 RELATIONSHIP BETWEEN GLYCEMIC VARIABILITY AND B-CELL FUNCTION IN ADULTS AT HIGH

RISK OF TYPE 2 DIABETES.

MA Szkudlinska, ML Neuhouser and KM Utzschneider, Seattle, WA. University of Washington

Abstract 248

2:15 MIXED MACRONUTRIENT MEALS NORMALIZE GLUCOSE AND INSULIN LEVELS IN IMPAIRED

GLUCOSE TOLERANT OBESE TEENAGE GIRLS.

AA Lynch, G Coe, K Nadeau and M Cree-Green, Wauwatosa, WI and Aurora, CO. Medical College of Wisconsin

Abstract 249

Gastroenterology

Babcock \#6 (Sunset Center)

Henry C. Lin and Christopher Chang, Presiding

12:30 THE PREVALENCE OF COLON ADENOMATOUS POLYPS IN ASIAN INDIANS.

$S$ Mann, J Wilson-Chiru and S Tejaswi, Sacramento, CA. University of California, Davis Medical Center

Abstract 250

12:45 ROLE OF THE LYMPHATIC SYSTEM IN THE PROGRESSION OF INFLAMMATORY BOWEL DISEASE TO COLORECTAL CANCER IN AN EXPERIMENTAL MOUSE MODEL.

$S$ Daley, J Washington, M Bernas, E Meister, J Thorn, P Kiela, N Tanoue, JS Alexander and M Witte, Tucson, AZ and Shreveport, LA. University of Arizona (WAFMR/WAP Student Subspecialty Award Winner) 
1:00 A REMEMBRANCE OF PROCEDURES PAST: LATE HEPATIC ARTERY THROMBOSIS.

$R$ Andrews, E Sheehan and M Lacy, Albuquerque, NM. University of New Mexico

Abstract 252

1:15 POST- INFECTIOUS IBS FOLLOWING RECURRENT/RELAPSING C. DIFFICILE ASSOCIATED DIARRHEA (CDAD).

$R$ Andrews and M Gavin, Albuquerque, NM. University of New Mexico

Abstract 253

1:30 COMPARISON OF TRANSCUTANEOUS RESPIRATORY MONITORING WITH CONVENTIONAL VITAL SIGNS IN THE DETECTION OF ABNORMAL RESPIRATORY EVENTS IN CHILDREN UNDERGOING ENDOSCOPY.

G Lui, Loma Linda, CA. Loma Linda University

Abstract 254

$1: 45$

State-of-the-Art Speaker

NEW INSIGHTS INTO PATHOPHYSIOLOGY OF POSTINFECTIOUS IBS.

Christopher Chang, University of New Mexico

Genetics

Rehearsal Room (Sunset Center)

Renata Gallagher and Margaret Adam, Presiding

12:30 UTILITY OF BROAD SEQUENCING TO REVEAL MTM1 GENE MUTATION CARRIERS WITH HISTORY OF RECURRENT NEONATAL DEATH.

VK Berger, A Alsadah and J Shieh, San Francisco, CA. University of California San Francisco

Abstract 255

12:45 EFFICACY AND SAFETY OF DIAZOXIDE CHOLINE CONTROLLED RELEASE TABLET IN

PRADER-WILLI SYNDROME: RESULTS OF THE DOUBLE-BLIND ARM OF THE STUDY.

A Surampalli, M Wencel, J Gold, N Cowen and V Kimonis, Irvine, CA; Loma Linda, CA and Carlsbad, CA.

University of California, Irvine (Abbott Subspecialty Award)

Abstract 256

1:00 CLINICAL COURSE OF 4 CHILDREN WITH GNAO1 MUTATIONS CAUSING A SEVERE AND DISTINCTIVE MOVEMENT DISORDER.

A Ananth, A Robichaux-Viehoever, A Hanson-Kahn, R Cox, G Enns, S Jonathan, M Willing, B Schlaggar, Y Wu and J Bernstein, Stanford, CA, San Francisco, CA, Palo Alto, CA and St. Louis, MO. Stanford University

Abstract 257

1:15 ALLAN HERNDON DUDLEY SYNDROME: A CASE REPORT AND REVIEW OF THE LITERATURE.

$S$ Dugan, Salt Lake City, UT. University of Utah

Abstract 258

1:30 A MASSIVELY PARALLEL APPROACH TO ASSESS THE SEQUENCE-FUNCTION RELATIONSHIP OF RECOMBINASE A.

DJ Lawrence, DM Fowler, GR Smith and JD Bloom, Seattle, WA. Fred Hutchinson Cancer Research Center

Abstract 259

1:45 DIAGNOSTIC OUTCOMES AND RELATIVE COST OF CLINICAL WHOLE EXOME SEQUENCING.

MR Ruzhnikov, A Alsadah, B Mendelsohn, A Alhariri, MR Cilio, Y Wu, EJ Marco, E Hsiao, J Sullivan, J Shieh, A Slavotinek and EH Sherr, Stanford, CA and San Francisco, CA. University of California, San Francisco (WSPR Mead Johnson Travel Award Winner)

Abstract 260 
2:00 A DOMINANT MUTATION ASSOCIATED WITH BOHRING-OPTIZ SYNDROME REVEALED DURING WHOLE EXOME SEQUENCING ANALYSIS.

C Carlston, T Tvrdik, R Mao and H Underhill, Salt Lake City, UT. University of Utah

Abstract 261

2:15 EHLERS-DANLOS SYNDROME, PROGEROID TYPE, CAUSED BY A NOVEL MUTATION, P.(CYS324SER) IN B4GALT7 IN A CHILD WITH JOINT LAXITY, GROWTH RETARDATION, DYSMORPHIC FACIAL FEATURES AND NOVEL EYE FINDINGS INCLUDING BILATERAL COLOBOMAS.

T Arunrut, M Sabbadini, M Jain, F Scaglia and A Slavotinek, San Francisco, CA and Houston, CA. University of California, San Francisco

Abstract 262

\section{Neonatal Pulmonary III}

Carpenter Hall

Parviz Minoo and Virender K. Rehan, Presiding

12:30 MATERNAL RACE/ETHNICITY (RE) AND INFANT GENETIC ANCESTRY ARE ASSOCIATED WITH SURVIVAL WITHOUT BRONCHOPULMONARY DYSPLASIA (BPD) IN PRETERM NEWBORNS TREATED WITH INHALED NITRIC OXIDE (INO).

RL Keller, S Oh, D Torgerson, P Ballard, S Huntsman, E Burchard, D Black and R Ballard, San Francisco, CA. University of California, San Francisco

Abstract 263

12:45 EARLY POSTNATAL HYPEROXIA INCREASES LUNG WNT3A AND MMP9 MRNA LEVELS IN GROWTH RESTRICTED RAT PUPS.

RA Knecht, Y Yang, C Zou, A Sainz and L Joss-Moore, Salt Lake City, UT. University of Utah

Abstract 264

1:00 INVASIVE MECHANICAL VENTILATION FOR 3 DAYS DOES NOT ALTER PROLIFERATION OF CARDIAC MYOCYTES COMPARED TO NON-INVASIVE NASAL VENTILATION.

N Punnanitinont, R Hicks, H Emerson, J Orchard, Z Wang, M Dahl, D Null, B Yoder and K Albertine, Salt Lake City, UT, Appleton, WI and Davis, CA. Lawrence University

Abstract 265

1:15 PERINATAL NICOTINE EXPOSURE INDUCES MESENCHYMAL MYOGENIC DIFFERENTIATION, BUT NOT EPITHELIAL-MESENCHYMAL TRANSITION IN RAT OFFSPRING LUNGS.

H Shen, R Sakurai, M Gong, J Liu and VK Rehan, Torrance, CA. Los Angeles Biomedical Research Institute at Harbor-UCLA Medical Center

Abstract 266

1:30 FROM MOUSE DEVELOPMENT TO SHEEP LUNG INJURY.

NS Bhopal, C Li, M Dahl, K Albertine, D Mathur and P Minoo, Los Angeles, CA and Salt Lake City, UT. LAC +USC Medical Center \& Children's Hospital Los Angeles

Abstract 267

1:45 ONE YEAR PULMONARY OUTCOMES IN THE TRIAL OF LATE SURFACTANT (TOLSURF).

RL Keller, E Rogers, E Eichenwald, A Hibbs, D Black, P Ballard and R Ballard, San Francisco, CA, Houston, TX and Cleveland, OH. University of California, San Francisco

Abstract 268

2:00 VENTILATION AFFECTS MECHANICAL PROPERTIES OF CEREBRAL ARTERIES IN PRETERM LAMBS.

M Converse, K Nye, K Monson and K Albertine, Salt Lake City, UT. University of Utah

Abstract 269

2:15 RANDOMIZED CONTROLLED TRIAL OF NEBULIZED N-ACETYLCYSTEINE IN A NEWBORN PIG MODEL OF MECONIUM ASPIRATION SYNDROME.

AA Simones, A Lampland, R Reed, M Mammel, C Worwa, M Toombs, A Ginder and KD Roberts, Saint Paul, MN and Minneapolis, MN. University of Minnesota Masonic Children's Hospital (WSPR Mead Johnson Travel Award Winner)

Abstract 270 
Neonatology General III

All Saints Church, Seccombe Hall

Camille Fung and Josephine M. Enciso, Presiding

12:30 EVIDENCE FOR MITOTIC TRANSMISSION OF NICOTINE'S EPIGENETIC EFFECTS ON MALE GONADAL GERM CELL UNDERLYING OFFSPRING LUNG MYOGENIC PHENOTYPE.

M Gong, J Liu, NS Murty and VK Rehan, Torrance, CA. Harbor-UCLA

Abstract 271

12:45 A 10 YEAR REVIEW OF CENTRAL LINE ASSOCIATED BLOOD STREAM INFECTION PREVENTION EFFORTS IN THE NEONATAL INTENSIVE CARE UNIT: ARE IMPROVEMENTS SUSTAINABLE?

$R$ Koeppel, C UY and K Quan, Orange, CA. University of California, Irvine

Abstract 272

1:00 INDUCTION OF HEME OXYGENASE-1 ATTENUATES THE SEVERITY OF SEPSIS IN A NON-SURGICAL NEONATAL MOUSE MODEL.

K Fujioka, S Lu, S Wong, F Kalish, H Zhao, RJ Wong and DK Stevenson, Stanford, CA. Stanford University School of Medicine

Abstract 273

1:15 A LIPID FORMULATION OF ZINC PROTOPORPHYRIN FOR THE PREVENTION OF NEONATAL HYPERBILIRUBINEMIA DUE TO CHRONIC HEMOLYSIS.

CM Konecny, K Fujioka, S Wong, S Lu, F Kalish, H Zhao, RJ Wong and DK Stevenson, Stanford, CA and La Jolla, CA. Stanford University School of Medicine

Abstract 274

1:30 SURGICAL PROCEDURES INCREASE PROGRESSION AND DURATION OF RETINOPATHY OF PREMATURITY (ROP).

C Torr, B Yoder and J Beachy, Salt Lake City, UT. University of Utah

Abstract 275

1:45 EFFECT OF ACUTE INTRAUTERINE ISCHEMIA ON NRF2 AND ANTIOXIDANT DEFENSES IN THE RAT PUP BRAIN.

E Calma, T Nguyen, M Zhang, T Liu, G Power and AB Blood, Loma Linda, CA. Loma Linda University

Abstract 276

2:00 BENZYL ALCOHOL POISONING RESURFACES IN CHRONICALLY VENTILATED PRETERM LAMBS. K Zuspan, S Bowen, C Bradford, L Pettet, M Dahl, D Null, B Yoder, R Ward and K Albertine, Salt Lake City, UT and Davis, CA. University of Utah

Abstract 277

2:15 PRETERM BIRTH DECREASES PPAR $\gamma$ PROTEIN ABUNDANCE IN THE ILEUM OF CHRONICALLY VENTILATED PREMATURE LAMBS.

LA Ruybal, L Dong, M Dahl, K Albertine and L Joss-Moore, Salt Lake City, UT. University of Utah

Abstract 278

\section{Neonatology Perinatal Biology I}

Chapman \#4 (Sunset Center)

Lauren Jantzie and Lisa Joss-Moore, Presiding

12:30 EFFECTS OF POST-INJURY DEXAMETHASONE THERAPY ON BRAIN INFARCT SIZE IN A RAT MODEL OF NEONATAL HYPOXIC-ISCHEMIC ENCEPHALOPATHY.

B Harding, Y Li, Q Ma and L Zhang, Loma Linda, CA. Loma Linda University Children's Hospital

12:45 FETAL LEUCINE INFUSION INCREASES LACTATE CONCENTRATIONS IN LATE GESTATION FETAL SHEEP.

A Blake, P Rozance, S Wesolowski, R Wilkening, WW Hay and LD Brown, Aurora, CO. University of Colorado 
1:00 SKELETAL MUSCLE GROWTH IS RESTRICTED DESPITE MAINTAINED HINDLIMB BLOOD FLOW AND OXYGEN CONSUMPTION IN THE LATE GESTATION IUGR FETUS.

L Zastoupil, A Blake, P Rozance, S Wesolowski, WW Hay, R Wilkening and LD Brown, Aurora, CO. University of Colorado School of Medicine

Abstract 281

1:15 DEVELOPMENTAL CHANGES IN ANTIOXIDANT DEFENSES IN THE PERINATAL BRAIN.

L Kim, F Najjar, M Zhang, E Calma, T Nguyen, T Liu, G Power and AB Blood, Redlands, CA. Loma Linda University

Abstract 282

1:30 HYDROCORTISONE PROTECTS THE BRAIN FROM HYPOXIC-ISCHEMIC INJURY IN NEONATAL

RATS.

KR Salcedo-Concepcion, Y Li and L Zhang, Loma Linda, CA. Loma Linda University

Abstract 283

1:45 MATERNAL TOBACCO SMOKE EXPOSURE IMPAIRS PLACENTAL FUNCTION AND INDUCES SEX-SPECIFIC ALTERATIONS IN FETAL FATTY ACIDS.

$C$ Weinheimer, M Fitzhugh, P Singh, Z Wang, J Jenkins, T Larsen, M Baack, K Albertine and L Joss-Moore, Salt Lake City, UT and Sioux Falls, SD. University of Utah (Abbott Subspecialty Award)

Abstract 284

2:00 EPITHELIAL MEMBRANE PROTEIN 2 (EMP2) DEFICIENCY ALTERS PLACENTAL ANGIOGENESIS MIMICKING FEATURES OF INTRAUTERINE GROWTH RESTRICTION.

A Chu, C Williams and M Wadehra, Los Angeles, CA and Research Triangle Park, NC. David Geffen School of Medicine at UCLA

Abstract 285

2:15 EFFECT OF PERINATAL DEVELOPMENT ON NRF2 AND ANTIOXIDANT DEFENSES IN THE RAT PUP BRAIN.

T Nguyen, E Calma, L Kim, M Zhang, T Liu, G Power and AB Blood, Loma Linda, CA. Loma Linda University

Surgery II

Conductor's Room

Subhas Gupta and Lee Pu, Presiding

12:30 ENHANCED RECOVERY IN PLASTIC SURGERY: A REVIEW OF THE LITERATURE AND A PROPOSAL OF ACTIONABLE MEASURES.

$C V V u$ and S Gupta, Westminster, CA. Loma Linda University

Abstract 287

12:45 GROWING DISPARITY IN COLLECTION RATES: THE EFFECT OF THE AFFORDABLE CARE ACT IN PLASTIC SURGERY.

I Campwala, N Biskup, S Motakef and S Gupta, Loma Linda, CA. Loma Linda University

Abstract 288

1:00 LACK OF INPUT SPECIFICITY, GREAT OUTCOME VARIABILITY, AND IMPRECISE RISK

CALCULATIONS: PITFALLS OF THE ACS-NSQIP RISK CALCULATOR IN PLASTIC SURGERY.

C Johnson, I Campwala and S Gupta, Loma Linda, CA. Loma Linda University

Abstract 289

1:15 PRELIMINARY CLINICAL EXPERIENCE WITH DEOXYCHOLIC ACID IN CONTOURING SUBMENTAL FAT.

DH Lee, J Chidester and S Gupta, Loma Linda, CA. Loma Linda University

Abstract 290 


\section{Western Meeting Program}

1:30 MANAGEMENT AND OUTCOMES OF INCIDENTAL DONOR DERIVED PULMONARY EMBOLISM. GR Dincheva, EL Bush, P Brandenhoff, M Brzezinski, JP Singer and J Kukreja, San Francisco, CA. University of California, San Francisco

Abstract 291

1:45 A RETROSPECTIVE STUDY ON DEMOGRAPHIC, CLINICAL, AND OUTCOME DATA OF WOMEN UNDERGOING SACROSPINOUS LIGAMENT FIXATION.

RJ Patel, JM Heusinkveld and KD Hatch, Tucson, AZ. University of Arizona

Abstract 292

2:00

DO CONVERSION TOTAL HIP ARTHROPLASTY YIELD COMPARABLE RESULTS TO PRIMARY TOTAL HIP ARTHROPLASTY?

G Chin, Daly City, CA. University of California, Irvine

Abstract 293

2:15 CAPITONNAGE FOR SURGICAL TREATMENT OF PULMONARY CYSTIC ECHINOCOCCOSIS: SYSTEMATIC REVIEW AND META-ANALYSIS.

C Logan and P Pottinger, Seattle, WA. University of Washington School of Medicine

Abstract 294 
CARMEL RESEARCH PRIZE RECIPIENT PRESENTATION II

Jointly sponsored by

WESTERN SECTION AMERICAN FEDERATION FOR MEDICAL RESEARCH
WESTERN SOCIETY FOR CLINICAL INVESTIGATION
WESTERN ASSOCIATION OF PHYSICIANS
WESTERN SOCIETY FOR PEDIATRIC RESEARCH
WESTERN STUDENT MEDICAL RESEARCH FORUM

Sunset Center - Studio 105

Friday, January 29, 2016

2:35 PM - 3:25 PM

Fred Buckner and Paul Rozance, Presiding

2:35 INFLUENCE OF PERIPHERAL INSULIN RESISTANCE AND HEPATIC LIPOGENESIS ON LIVER FAT IN OBESE PCOS GIRLS.

Melanie Cree Green, MD, PhD, University of Colorado School of Medicine

3:00 PESTICIDES AND PERSISTENT POLLUTANTS: EFFECTS ON CHILD AND ADULT HEALTH.

Jose R Suarez, MD, MPH, PhD, University of California San Diego

\section{CONCURRENT SESSIONS}

Friday, January 29, 2016

3:30 PM - 6:00 PM

Jointly sponsored by

WESTERN SECTION AMERICAN FEDERATION FOR MEDICAL RESEARCH

WESTERN SOCIETY FOR CLINICAL INVESTIGATION

WESTERN ASSOCIATION OF PHYSICIANS

WESTERN SOCIETY FOR PEDIATRIC RESEARCH

WESTERN STUDENT MEDICAL RESEARCH FORUM

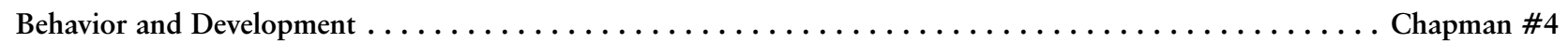

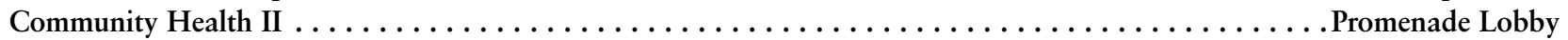

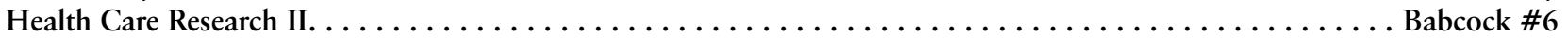

Hematology and Oncology II . . . . . . . . . . . . . . . . . . . . . . . . . . . Carpenter Hall

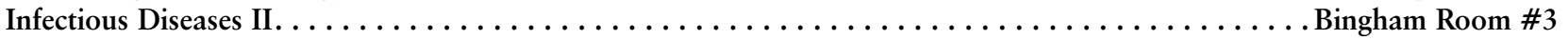

Morphogenesis and Malformations $\ldots \ldots \ldots \ldots \ldots \ldots \ldots \ldots \ldots \ldots \ldots \ldots \ldots \ldots \ldots \ldots \ldots \ldots \ldots \ldots \ldots \ldots$ Rearsal Room Neonatology General IV . . . . . . . . . . . . . . . . . . . . . . . . All Saints Church, Seccombe Hall

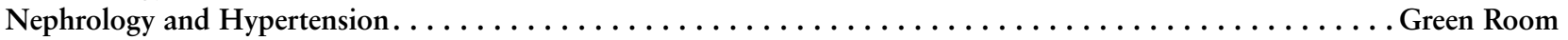

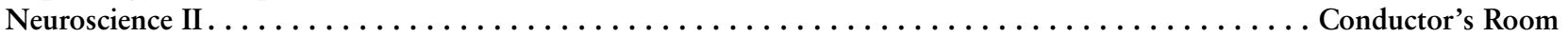

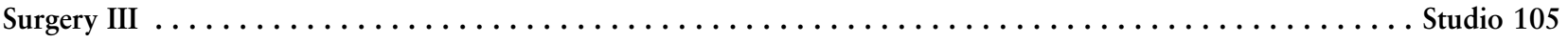


Behavior and Development

Chapman \#4 (Sunset Center)

Nicole Tartaglia and Katbleen Angkustsiri, Presiding

3:30 ASSOCIATIONS AMONG MOTHER-TODDLER PLAY AND DEVELOPMENT IN PRETERM TODDLERS. N Moss, D Novak, R Rieger, J Fuller, S Erickson and JR Lowe, Albuquerque, NM. University of New Mexico (Abbott Subspecialty Award)

Abstract 295

3:45 EXPLORING SEX DIFFERENCES IN AUTISM SPECTRUM DISORDERS USING THE CHARGE STUDY. $M$ White, K Angkustsiri, D Tancredi and R Hansen, Sacramento, CA. University of California, Davis Medical Center

Abstract 296

4:00 WHAT MIGHT EXPLAIN SOCIAL IMPAIRMENTS IN CHILDREN WITH CHROMOSOME 22Q11.2 DELETION SYNDROME?

K Angkustsiri, I Leckliter and TJ Simon, Sacramento, CA. University of California, Davis Medical Center

Abstract 297

4:15 THE EFFECTS OF ANIMAL ASSISTED INTERVENTION ON THE SOCIAL INITIATION BEHAVIORS OF CHILDREN WITH AN AUTISM SPECTRUM DISORDER.

H Albasha, M Kelly, J Andrews and S Rice, Oro Valley, AZ. The University of Arizona College of Medicine Tucson

Abstract 298

4:30 State-of-the-Art Speaker

SLEEP DIFFERENCES IN CHILDREN WITH AUTISM SPECTRUM DISORDERS: RESEARCH UPDATES.

Ann Reynolds, University of Colorado School of Medicine

5:00 IMPACT OF ERYTHROPOIESIS STIMULATING AGENTS ON BEHAVIORAL MEASURES IN INFANTS BORN PRETERM AND TERM.

R Rieger, RA Yeo, S Winter, J Phillips, N Moss, RK Ohls and JR Lowe, Albuquerque, NM and Salt Lake City, UT. University of New Mexico (Abbott Subspecialty Award)

Abstract 299

5:15 DEVELOPMENTAL MILESTONES BOOKLETS AID IN EARLY DIAGNOSIS/INTERVENTION.

P Kaluzhny and S Lee, Las Vegas, NV. University of Nevada School of Medicine

Abstract 300

5:30 ADHERENCE TO A DEPRESSIVE DISORDERS CLINICAL PATHWAY IS ASSOCIATED WITH LONGER LENGTH OF STAY.

B Lifland, A Desai, D Wright, R Mangione-Smith and K Schloredt, Seattle, WA. University of Washington School of Medicine

Abstract 301

5:45 PARENTAL PERCEPTIONS ABOUT EXERCISE AND ADHD.

SC Cohen, S Taylor, R Rashedi, A Ramakrishnan, R Hansen and J Schweitzer, Sacramento, CA and Davis, CA.

University of California, Davis MIND Institute

Abstract 302

Community Health II

Promenade Lobby (Sunset Center)

Jay Erickson, Presiding

3:30 A PROGRESSIVE AND INNOVATIVE APPROACH TO INCREASE THE VARIETY OF RESIDENT EXPOSURE TO UNDERSERVED COMMUNITIES.

SU Das, M Hogan, D Simangan and E Guenechea, Las Vegas, NV. University of Nevada School of Medicine

Abstract 303 
3:45 BEFORE IT'S TOO LATE $\Rightarrow$ VACCINATE: SCHOOL BASED VACCINATION CLINIC IN CONRAD, MT. JS Kranseler, Seattle, WA. University of Washington School of Medicine

4:00 ECOURAGING EARLY LITERACY IN THE SWINOMISH INDIAN TRIBAL COMMUNITY THROUGH REACH OUT AND READ.

LC Thornquist, Seattle, WA. University of Washington

Abstract 305

4:15 INCREASING INFANT VACCINATION RATES IN PARK COUNTY, MONTANA BY PRENATAL VACCINATION EDUCATION.

A Seeley, Kirkland, WA. University of Washington School of Medicine

Abstract 306

4:30 'NO SMOKING' SIGNS IN THE CITY PARKS OF EPHRATA, WASHINGTON.

DE Marriott, Seattle, WA. University of Washington School of Medicine

Abstract 307

4:45 QUALITY IMPROVEMENT INTERVENTION TO IMPROVE ANNUAL PAPANICOLAOU SMEAR RATES AMONG HUMAN IMMUNODEFICIENCY VIRUS-INFECTED WOMEN.

V Ganta, D Patel, S Moonie, A Hunt, J Richardson, D Di John and E Ezeanolue, Las Vegas, NV. University of Nevada Medical Center

Abstract 308

5:00 ADDICTION BEFORE BIRTH: DRUG ABUSE DURING PREGNANCY.

RC Braunberger, Seattle, WA. University of Washington School of Medicine

Abstract 309

5:15 SEXUAL HEALTH AWARENESS COURSE AT FORT PECK COMMUNITY COLLEGE: PEER-EDUCATION, PREVENTION, AND TREATMENT OF SEXUALLY TRANSMITTED INFECTIONS.

SF Colvin, Seattle, WA. University of Washington School of Medicine

Abstract 310

5:30 COMPARING THE EDUCATIONAL OUTCOME OF UNDERREPRESENTED IN MEDICINE (URM) AND NON-URM STUDENT PARTICIPANTS IN A HEALTH ENRICHMENT PROGRAM.

N Rezakahn Khajeh, MJ Vennat and B Afghani, Irvine, CA and Orange, CA. University of California, Irvine

Abstract 311

$5: 45$

AN EXCHANGE FOR HEALTH: IMPLEMENTING A SYRINGE EXCHANGE PROGRAM IN BROWNING, MT.

JL Ebner, Seattle, WA. University of Washington

Abstract 312

Health Care Research II

Babcock \#6 (Sunset Center)

Edward Lee, Presiding

$3: 30$

State-of-the-Art Speaker

QUALITY IMPROVEMENT IN CARDIOVASCULAR DISEASE IN LOW AND MIDDLE INCOME

COUNTRIES,

Edward Lee, Keck School of Medicine of University of Southern California

4:00 PATIENT WRITTEN NOTES AND THEIR USE IN PRIMARY CARE: "I FELT LIKE I WAS ABLE TO BE HEARD".

MO Anderson, S Jackson, N Oster, S Peacock and J Elmore, Missoula, MT. University of Washington School of

Medicine (WAFMR/WAP Student Subspecialty Award Winner)

Abstract 313 
4:15 PROVIDER/STAFF PERCEPTIONS OF ONLINE PORTAL BARRIERS AND BENEFITS IN A SAFETY NET SETTING.

M Shah, L Tieu and CR Lyles, Pomona, CA and San Francisco, CA. Western University of Health Sciences

Abstract 314

4:30 LISTENING BEYOND AUSCULTATING: A QUALITY INITIATIVE TO IMPROVE HCAHPS COMMUNICATION SCORES.

AN Schneider, E Asher, JR Cartwright, JL Chow, ED Lee, M Nordstrom, MD Schwarz, M Zarin-Pass, L Mazotti and NS Riegels, San Francisco, CA and Oakland, CA. University of California, San Francisco

Abstract 315

4:45 PREVALENCE OF HOT THYROID NODULES SUSPICIOUS FOR MALIGNANCY.

D Chang, S Lippman, A Semrad and A Swislocki, Martinez, CA and Sacramento, CA. University of California,

Davis School of Medicine

Abstract 316

5:00 REMOVING BARRIERS TO MEDICATION NON-COMPLIANCE: PATIENTS' USE OF A DRUG PRICE COMPARISON WEBSITE TO REDUCE COSTS AND IMPROVE ADHERENCE.

S Orrange, M Ivanova and S Sambasivam, Los Angeles, CA and Cambridge, MA. Keck School of Medicine of University of Southern California

Abstract 317

5:15 THE IMPACT OF FIRST RESPONDER TURNOUT SEGMENT ON SURVIVAL FROM OUT-OF-HOSPITAL CARDIAC ARREST.

NP DeRuyter, S Husain, LYin, M Olsufka, AM McCoy, C Maynard, LA Cobb, TD Rea and MR Sayre, Seattle, WA. University of Washington School of Medicine

Abstract 318

5:30 PROSPECTIVE COHORT STUDY OF REMOTE EAR DISEASE DIAGNOSIS USING A SMARTPHONE OTOSCOPE.

MR LaCourse, M Whipple, C Hume, JD Scott and MG Sardesai, Seattle, WA. University of Washington School of Medicine

Abstract 319

5:45 HIGH-FLUENCE LIGHT EMITTING DIODE-GENERATED RED LIGHT MODULATES KEY CELLULAR CHARACTERISTICS OF SKIN FIBROSIS IN HUMAN SKIN FIBROBLASTS.

A Mamalis, E Koo and J Jagdeo, Sacramento, CA. University of California, Davis

Abstract 320

Hematology and Oncology II

Carpenter Hall

Jorge Nieva and Thomas Deloughery, Presiding

3:30 PRETREATMENT CLINICAL PROGNOSTIC FACTORS FOR BRAIN METASTASES FROM BREAST CANCER TREATED WITH GAMMA KNIFE RADIOSURGERY.

AT Roehrig, EA Ferrel, D Benincosa, B Peressini, A MacKay and CM Lee, Seattle, WA; Spokane, WA and Coeur D'Alene, ID. University of Washington

Abstract 321

3:45 EVALUATION OF MICRONUCLEI FREQUENCY IN CULTURED PERIPHERAL BLOOD LYMPHOCYTES OF PROSTATE CANCER PATIENTS BEFORE AND AFTER PROTON RADIOTHERAPY.

$B$ Chou, M Vazque and A Bertucci, Colton, CA. Loma Linda University

Abstract 322

4:00 ASSESSMENT OF RASSF1C PIRNA-TARGET GENES IN LUNG TUMOR TISSUES.

C Sittlinger, O Fawibe, E Ramley, M Firek, Y Amaar and M Reeves, Loma Linda, CA and Collegedale, TN. Loma

Linda University School of Medicine

Abstract 323 
4:15 MINIBEAM THERAPY AND TISSUE SPARING POTENTIAL.

A Vassantachart, R Tailor, A Dilmanian, J Eley and S Krishnan, Houston, TX; Stony Brook, NY; Baltimore, MD and Loma Linda, CA. Loma Linda University

Abstract 324

4:30 IMMUNOLOGIC PROFILE OF HEAD AND NECK SQUAMOUS CELL CARCINOMA CANCER STEM CELLS.

E Warnock, H Serracino, M Glogowska, A van Bokhoven, S Keysar, M Lucia and A Jimeno, Aurora, CO. University of Colorado

Abstract 325

4:45 EVALUATION OF MLNO264 AS A NOVEL THERAPY FOR PANCREATIC CANCER.

A Schreiber, S Bagby, K Quackenbush, W Messersmith and J Arcaroli, Denver, CO. University of Colorado School of Medicine

Abstract 326

5:00 PRECLINICAL EVALUATION OF THE TRANSLATIONAL INHIBITOR SVC112 IN COLORECTAL CANCER.

K Robertson, J Tentler, P Klauck, S Bagby, T Pitts, J Kim and S Eckhardt, Aurora, CO. University of Colorado School of Medicine

Abstract 327

5:15 CENTRAL LINE ASSOCIATED BLOOD STREAM INFECTIONS IN PEDIATRIC HEMATOLOGY/ ONCOLOGY INPATIENTS AND OUTPATIENTS.

A Cruickshank, WH Meyer and T Carroll, Edmond, OK and Oklahoma City, OK. University of Oklahoma (WAFMR Scholar Awardee)

Abstract 328

5:30 CORRELATION BETWEEN EPITHELIAL-MESENCHYMAL TRANSITION AND INVASIVENESS IN OVARIAN CANCER CELL LINES AND ORTHOTOPIC XENOGRAFT.

M McCarthy, H Campos, T Suzuki, A Hill, L Sanderman and J Unternaehrer, Loma Linda, CA. Loma Linda University

Abstract 329

5:45 QUALITY OF ONLINE RESOURCES FOR PANCREATIC CANCER PATIENTS.

L DeGroot and P Ingledew, Vancouver, BC, Canada and Surrey, BC, Canada. University of British Columbia

Abstract 330

Infectious Diseases II

Bingham Room \#3 (Sunset Center)

Ravi Durvasula, Fred Buckner and David Gilbert, Presiding

3:30 IDENTIFYING MEN WHO HAVE SEX WITH MEN AND TRANSGENDER WOMEN WHO HAVE POOR LINKAGE TO HIV CARE IN LIMA, PERU.

A Primbas, M Villaran and A Duerr, Seattle, WA and Lima, Peru. University of Washington School of Medicine

Abstract 331

3:45 EFFECTS OF INTERFERON GAMMA ON THE RESPIRATORY BURST OF VARIANT X-LINKED CHRONIC GRANULOMATOUS DISEASE PATIENTS VERSUS CLASSIC X-LINKED DISEASE. HR Hill, NH Augustine, LA Miles, J Rejali, KO Woodbury, B Pasi, TB Martins and A Kumanovics, Salt Lake City, UT. University of Utah

Abstract 332

4:00 DISSEMINATED COCCIDIOIDOMYCOSIS IN CHILDREN.

JM Lee, M Tablizo and A Graciano, Fresno, CA and Madera, CA. University of California, Fresno

Abstract 333 
4:15 IMPACT OF RAPID ORGANISM IDENTIFICATION WITH MATRIX-ASSISTED LASER DESORPTION/ IONIZATION TIME-OF-FLIGHT ON OUTCOMES IN HOSPITALIZED PEDIATRIC PATIENTS.

L Herrera, K Culbreath and W Dehority, Albuquerque, NM. University of New Mexico School of Medicine

4:30 SALMONELLA OSTEOMYELITIS IN IMMUNOCOMPETENT CHILDREN: A CASE SERIES AND REVIEW OF THE LITERATURE.

DF Pavlik, A Gill, M Muller, J Eldredge, M Eickman and W Dehority, Albuquerque, NM. University of New Mexico (WAFMR/WAP Outstanding Resident Award Winner)

Abstract 335

4:45 EFFECTIVENESS OF POWERPOINT PRESENTATIONS IN TEACHING EMERGENT DERMATOSIS TO PEDIATRIC RESIDENTS.

GG Still, H Chandnani, S Palathumpat, and O Ingaramo, Las Vegas, NV. University of Nevada Medical Center Abstract 336

$5: 00$

EXPRESSION PATTERNS OF HEME OXYGENASE-1 IN IMMUNE CELLS DURING LATE GESTATIONAL INFLAMMATION.

M Ozen, H Zhao, F Kalish, Y Yang, DB Lewis, RJ Wong and DK Stevenson, Stanford, CA. Stanford University

School of Medicine (WAFMR Scholar Awardee)

Morphogenesis and Malformations

Rehearsal Room (Sunset Center)

Marilyn C. Jones and Margaret Adam, Presiding

3:30 State-of-the-Art Speaker

THE CELLULAR AND MOLECULAR MECHANISMS UNDERLYING UNUSUAL INHERITANCE IN

CRANIOFRONTONASAL SYNDROME.

Jeffrey O. Bush, University of California, San Francisco

4:00 MICROPHTHALMIA WITH LIMB ANOMALIES (MIM \#206920). A RECOGNIZABLE SYNDROME INVOLVING THE DEVELOPMENT OF THE EYES, BRAIN AND LIMBS.

M Del Campo, I Odom, L Gist, J Dwek and KL Jones, La Jolla, CA. University of California San Diego

Abstract 338

4:15 CHEST WALL ASYMMETRY AND ABSENT LUNG IN UNIPARENTAL DISOMY 16.

T Wilson, S Dugan and JC Carey, Salt Lake City, UT. University of Utah (WSPR Mead Johnson Travel Award Winner)

Abstract 339

4:30 CLASSIFYING CONGENITAL DEFECTS BY CAUSE AND CLINICAL PRESENTATION: A POPULATION-BASED STUDY IN UTAH.

ML Feldkamp, LD Botto, J Byrne, S Krikov and JC Carey, Salt Lake City, UT. University of Utah

Abstract 340

4:45 MESODERM LOSS OF SONIC HEDGEHOG AND TGF-BETA SIGNALING CAUSE TRACHEAL MALFORMATIONS.

D Mathur, NS Bhopal, A Fischer and P Minoo, Los Angeles, CA. LAC+USC Medical Center (Abbott Subspecialty Award)

Abstract 341

5:00 FUNCTIONAL ENGRAFTMENT OF MURINE MC3T3-E1 PRE-OSTEOBLASTIC CELLS IN A ZEBRAFISH MODEL OF EPIMORPHIC REGENERATION.

BG Douglass, RY Kwon and CH Allan, Seattle, WA. University of Washington

Abstract 342 
5:15 CRANIOSYNOSTOSIS: VARIANT SEQUENCE ANALYSIS OF THE THYROID SIGNALING PATHWAY.

AE Lewis, Seattle, WA. University of Washington School of Medicine

Abstract 343

5:30 GASTROINTESTINAL FEATURES IN A NEWBORN WITH CURRY-JONES SYNDROME.

K Wigby, R Broderick, J Law, KP Davenport, S Bickler and MC Jones, San Diego, CA. University of California San Diego

Abstract 344

5:45 A NOVEL DE NOVO MUTATION IN CACNA1A IS ASSOCIATED WITH ATYPICAL NEUROLOGICAL FEATURES AND MITOCHONDRIAL DYSFUNCTION.

NN Derar, C Brown, J Platt and G Enns, Stanford, CA and Pleasant Hill, CA. Stanford University

Neonatology General IV

All Saints Church, Seccombe Hall

Robin K. Ohls and Sonia Bonifacio, Presiding

JOAN E. HODGMAN LECTURE:

GLOBAL CHILD HEALTH-2015 AND BEYOND. THE MOVING PARTS.

William Keenan, Saint Louis University School of Medicine

4:00 DELAYED EPO THERAPY IMPROVES BEHAVIORAL AND HISTOLOGICAL OUTCOMES AFTER NEONATAL RODENT STROKE.

A Larpthaveesarp, M Georgevits, D Ferriero and F Gonzalez, San Francisco, CA. University of California, San Francisco

Abstract 346

4:15 A PHASE II RANDOMIZED CONTROLLED TRIAL OF ERYTHROPOIETIN AND HYPOTHERMIA FOR NEONATAL NEUROPROTECION IN HYPOXIC-ISCHEMIC ENCEPHALOPATHY.

S Juul, F Gonzalez, K Van Meurs, R Ballard and Y Wu, for the NEATO Trial Group, Palo Alto, CA, San Francisco, CA and Seattle, WA. University of California, San Francisco

Abstract 347

4:30 DECREASED RISK OF CEREBELLAR HEMORRHAGE IN PREMATURE NEWBORNS EXPOSED TO ANTENATAL MAGNESIUM SULFATE.

D Gano, M Ho, HC Glass, D Xu, AJ Barkovich and D Ferriero, San Francisco, CA. University of California, San Francisco (WSPR Mead Johnson Travel Award Winner)

Abstract 348

4:45 MEASURING CALPROTECTIN IN STOOL AS PART OF THE "RULE OUT NECROTIZING ENTEROCOLITIS" EVALUATION.

B MacQueen, R Christensen, D Lambert, V Baer, M Sheffield, C Yost, E Gerday, R Schlaberg, J Lowe, J Shepard and M Cody, Salt Lake City, UT. University of Utah (Abbott Subspecialty Award)

Abstract 349

5:00 OUTCOMES OF EXTREMELY LOW BIRTH WEIGHT INFANTS WITH TRANSIENT HYPERGLYCEMIA TREATED WITH INSULIN.

K Barseghyan, R Ramanathan, L Barton and R Cayabyab, Los Angeles, CA. LAC+USC

Abstract 350

5:15 IDENTIFICATION OF NEONATAL HEMOLYSIS IN THE WELL BABY NURSERY.

S Srinivas, ME Castillo Cuadrado, RJ Wong, DK Stevenson and VK Bhutani, Stanford, CA. Stanford University

School of Medicine

Abstract 351 
5:30 NON-INVASIVE VENTILATION AND THE EFFECT ON INTUBATION IN NEWBORNS WITH RESPIRATORY DISTRESS SYNDROME: A POPULATION BASED STUDY.

T Chavez, A Lakshmanan, NP Iyer, T Stavroudis, A Garingo, PS Friedlich and R Ramanathan, Los Angeles, CA. Children's Hospital Los Angeles and LAC+USC Medical Center, Keck School of Medicine, University of Southern California

Abstract 352

5:45 IMPACT OF EXTRACORPOREAL MEMBRANE OXYGENATION ON CEREBRAL METABOLISM IN THE NEWBORN BRAIN.

AJ Reitman, PS Friedlich, J Stein, L Paquette, R Chapman, MD Nelson, JL Wisnowski and S Bluml, Los Angeles, CA. LAC+USC Medical Center, Keck School of Medicine of University of Southern California

Abstract 353

\section{Nephrology and Hypertension}

Green Room (Sunset Center)

Charles Edelstein, Presiding

3:30 ASSESSMENT OF URINE PROTEIN DIPSTICK AND PROTEIN/CREATININE RATIO AS DIAGNOSTIC TESTS IN CHILDHOOD NEPHROTIC SYNDROME.

A Sanchez, D Matsell, LWang, M Catapang, NM Polderman, A Roshan and C Mammen, Vancouver, BC, Canada. University of British Columbia

Abstract 354

3:45 PHYSICAL ACTIVITY AND METABOLIC HEALTH IN CHRONIC KIDNEY DISEASE.

WE Bowlby, L Zelnick, C Robinson-Cohen and IH DeBoer, Seattle, WA. University of Washington

Abstract 355

4:00 RENAL OUTCOMES IN PEDIATRIC ANTI-NEUTROPHIL CYTOPLASMIC ANTIBODY ASSOCIATED VASCULITIS - A PEDIATRIC VASCULITIS INITIATIVE (PEDVAS) STUDY.

A Chen, C Mammen, D Cabral and K Morishita, Vancouver, BC, Canada. University of British Columbia

Abstract 356

4:15 COMPLEMENT INHIBITION FOR PREVENTION AND TREATMENT OF ANTIBODY-MEDIATED REJECTION.

SC Jordan, J Choi and AVo, Los Angeles, CA. Cedars-Sinai Medical Center

Abstract 357

4:30 NF-KB TRANSCRIPTIONAL INHIBITION AMELIORATES CISPLATIN-INDUCED ACUTE KIDNEY INJURY (AKI).

C Edelstein, A Ozkok, Q Wang, D Ljubanovic and K Ravichandran, Aurora, CO and Zagreb, Croatia. University of Colorado Denver

Abstract 358

4:45 DYING MITOCHONDRIA: REDUCTION OF MITOCHONDRIAL PROTEINS IN PROGRESSIVE KIDNEY DISEASE.

YAghajan, M Darshi, S Miyamoto and K Sharma, San Diego, CA. University of California, San Diego (WAFMR/WAP Student Subspecialty Award Winner)

Abstract 359

Neuroscience II

Conductor's Room

Marie-Francoise Chesselet, Presiding

3:30 THE ROLE OF DIACYLGLYCEROL LIPASE IN THE TESTOSTERONE-INDUCED ENHANCEMENT OF RETROGRADE ENDOCANNABINOID SIGNALING IN EXCITATORY INPUTS TO ANOREXIGENIC PRO-OPIOMELANOCORTIN NEURONS.

JL Goethel and E Wagner, Pomona, CA. Western University of Health Sciences

Abstract 360 
3:45 ANDROGENS RAPIDLY POTENTIATE RETROGRADE ENDOCANNABINOID-MEDIATED INHIBITION OF ANOREXIGENIC POMC NEURONS.

D Fischer and E Wagner, Pomona, CA. Western University of Health Sciences

Abstract 361

4:00 THE ROLE OF DIACYLGLYCEROL LIPASE IN THE ANDROGENIC REGULATION OF ENERGY HOMEOSTASIS.

$R$ Propst and E Wagner, Ontario, CA. Western University of Health Sciences

Abstract 362

4:15 CALPAIN-2 AND PROTEIN TYROSINE PHOSPHATASE NON-RECEPTOR TYPE 13 COLOCALIZATION IN HIPPOCAMPUS OF ADULT WILDTYPE MICE.

A Kamgar-Parsi, M Baudry and Y Wang, Pomona, CA. Western University of Health Sciences

Abstract 363

4:30 IN UTERO HYPOXIA-ISCHEMIA AND LIPOPOLYSACCHARIDE ADMINISTRATION IN RATS INDUCES DEFICITS IN COGNITION EVALUATED USING A NOVEL TOUCHSCREEN PLATFORM.

$L$ Chan, S Robinson and L Jantzie, Albuquerque, NM and Boston, MA. University of New Mexico

Abstract 364

4:45 INFANTILE TRAUMATIC BRAIN INJURY IS MITIGATED BY ERYTHROPOIETIN TREATMENT IN A PRECLINICAL RODENT MODEL.

L Chan, J Denson, J Winer, J Maxwell, S Robinson and L Jantzie, Albuquerque, NM and Boston, MA. University of New Mexico

Abstract 365

5:00 OXIDATIVELY DEGRADED MITOCHONDRIAL DNA IS A NEWLY IDENTIFIED DAMP FAMILY MEMBER IN ASTROCYTES, AND POTENTIAL TRIGGER OF ALZHEIMER'S DISEASE.

A Mathew and S Hushmendy, Albany, NY. Albany Medical Center

Abstract 366

5:15 LEARNING AND MEMORY TESTING IN LAMBS.

$S$ Bowen, A Havlicak, J Beachy, M Dahl, D Null, B Yoder and K Albertine, Salt Lake City, UT; New York, NY and Davis, CA. University of Utah

Abstract 367

Surgery III

Studio 105 (Sunset Center)

Subhas Gupta and Lee Pu, Presiding

3:30 SAFETY AND EFFICACY OF LIPOSOMAL BUPIVICAINE ACROSS A SPECTRUM OF PLASTIC SURGERY PROCEDURES.

I Campwala, J Chidester and S Gupta, Loma Linda, CA. Loma Linda University

Abstract 368

3:45 AN EVALUATION OF ANTIHISTAMINE PRE-TREATMENT IN FACIAL INJECTABLE TREATMENTS.

$J$ Wendt, J Chidester and S Gupta, Loma Linda, CA. Loma Linda University

Abstract 369

4:00 INTEGRA FLOWABLE WOUND MATRIX AND THE LOWER EXTREMITY: IMPLICATIONS FOR THE RECONSTRUCTIVE LADDER.

C Johnson and S Gupta, Loma Linda, CA. Loma Linda University

Abstract 370

4:15 SPIDER SILK AS A NEXT GENERATION SUTURE.

ME Shapiro, Seattle, WA. University of Washington

Abstract 371 


\section{Western Meeting Program}

4:30 VAGINAL WALL SLING: PILOT STUDY OUTCOMES AND VIDEO DEMONSTRATION OF TECHNIQUE. S Cheriyan, J Bailey, KY Kim, M Keheila, J Shen and A Staack, Loma Linda, CA and Redlands, CA. Loma Linda University

Abstract 372

4:45 DEVELOPMENT OF AN IMPLANTABLE CHITOSAN HEMOSTAT.

M Dopp, Loma Linda, CA. Loma Linda University

Abstract 373

5:00 EFFICACY OF ANTEGRADE AND RETROGRADE WARM SALINE PERFUSION DURING RENAL CRYOABLATION FOR URETERAL PRESERVATION.

A Erskine, N Khater, P Yang, J Smith and D Baldwin, Loma Linda, CA. Loma Linda University

5:15 AN ANALYSIS OF INFECTIOUS RISK FROM ENDOSCOPIC VALVE BACKFLOW DURING URETEROSCOPY.

AR Kutzner, J Shen, S Abourbih, C Ritchie, D Baldwin and A Erskine, Colton, CA. Loma Linda University

5:30 DAMAGE TO POLYTETRAFLUOROETHYLENE-COATED GUIDEWIRES: A POTENTIAL FOREIGN BODY RISK.

AL Wong, A Erskine, AR Kutzner, S Abourbih, S Cheriyan, P Yang, DS Boskovic and D Baldwin, Loma Linda, CA. Loma Linda University

Abstract 376

5:45 INCIDENCE AND RISKS IN THE DEVELOPMENT OF PIN-SITE INFECTIONS AFTER PELVIC EXTERNAL FIXATION.

C McDonald, R Firoozabadi, J Agel and C Kleweno, Seattle, WA. University of Washington School of Medicine 


\section{CONCURRENT SESSIONS}

Saturday, January 30, 2016

8:00 AM - 10:00 AM

Jointly sponsored by

\section{WESTERN SECTION AMERICAN FEDERATION FOR MEDICAL RESEARCH \\ WESTERN SOCIETY FOR CLINICAL INVESTIGATION \\ WESTERN ASSOCIATION OF PHYSICIANS \\ WESTERN SOCIETY FOR PEDIATRIC RESEARCH \\ WESTERN STUDENT MEDICAL RESEARCH FORUM}

Adolescent Medicine and General Pediatrics III $\ldots \ldots \ldots \ldots \ldots \ldots \ldots \ldots \ldots \ldots \ldots \ldots \ldots$ Rehearsal Room

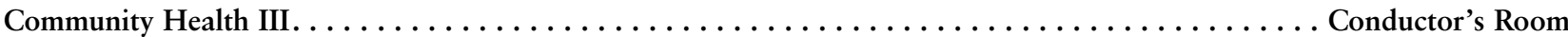

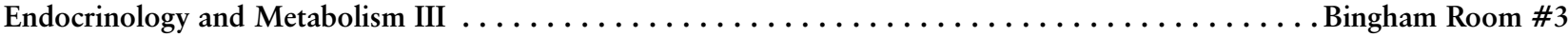

General Internal Medicine and Aging. . . . . . . . . . . . . . . . . . . . . . . . . . Babcock \#6

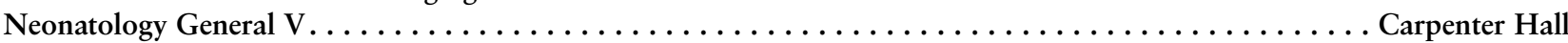

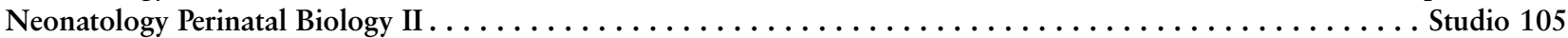

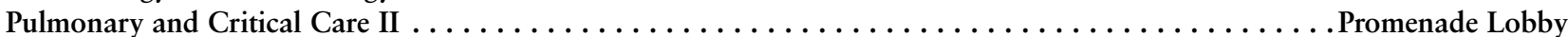

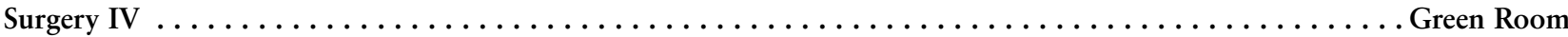

Adolescent Medicine and General Pediatrics III

Rehearsal Room (Sunset Center)

Craig Wong and Walter Dehority, Presiding

8:00 A CLOSE LOOK AT THE USE OF HYPERTONIC SALINE AND HIGH FLOW OXYGEN IN PEDIATRIC PATIENTS HOSPITALIZED WITH RESPIRATORY SYNCYTIALVIRUS.

C Mercurio, J Green and B Afghani, Irvine, CA and Orange, CA. University of California, Irvine

Abstract 378

8:15 COMPARING THE HABITS AND GOALS OF UNDERPREVILEGED AND PRIVILEDGED YOUTH.

K Nikroo, Irvine, CA. University of California, Irvine

Abstract 379

8:30 THE VALUE OF THROMBOPROPHYLAXIS IN PEDIATRIC CANCER PATIENTS WITH CENTRAL

VENOUS CATHETERS (CVC): A CLOSER LOOK AT THE LITERATURE.

F Aguirre, L Sekiguchi, KJ Yeung, M Alcayde, J Epstein, N Chintalapati, A Le, A Mehta and B Afghani, Irvine, CA and Orange, CA. University of California, Irvine

Abstract 380

8:45 EFFECTS OF RISPERIDONE USE IN PEDIATRIC POPULATION WITH ATTENTION DEFICIT HYPERACTIVITY DISORDER (ADHD).

AJ Garcia, N Kim, J Chang, S Ravikumar, A Morehouse, A Sidhu, A Lee and B Afghani, Los Angeles, CA, Irvine, $\mathrm{CA}$ and Orange, CA. University of California, Los Angeles

Abstract 381

9:00 COMMUNITY ACQUIRED- METHICILLIN RESISTANT STAPHYLOCOCCUS AUREUS (CA-MRSA)

INDUCED NECK ABSCESS ASSOCIATED WITH STRIDOR IN A 2-MONTH-OLD INFANT.

BH Hammond and H Agarwal, Albuquerque, NM. University of New Mexico

Abstract 382

9:15 DIETARY INTAKES AND GROWTH PATTERNS IN FORMULA-FED INFANTS CONSUMING A MEAT

OR DAIRY-BASED COMPLEMENTARY DIET.

KE Griese, M Tang, NF Krebs and AE Hendricks, Aurora, CO. University of Colorado Denver School of Medicine

Abstract 383

9:30 IDIOPATHIC PULMONARY HEMOSIDEROSIS PRESENTING AS SEVERE ANEMIA: A CASE REPORT.

$M$ Cohen and C Nakamura, Las Vegas, NV. University of Nevada

Abstract 384 
9:45 NUTRITIONAL INTAKE OF CHILDREN WITH NEPHROTIC SYNDROME.

NM Polderman, M Cushing, D Matsell, M Catapang, A Sanchez and C Mammen, Vancouver, BC, Canada. British Columbia Children's Hospital

Community Health III

Conductor's Room

Martin Teintze, Presiding

8:00 MEDIA LITERACY EDUCATION TO PREVENT ELECTRONIC NICOTINE DELIVERY SYSTEM USE BY ADOLESCENTS.

A Watson, Seattle, WA. University of Washington School of Medicine

Abstract 386

8:15 OBESITY AND DIABETES PREVENTION EDUCATION IN LINCOLN PUBLIC SCHOOLS.

$H$ Kibort-Crocker, Seattle, WA. University of Washington School of Medicine

Abstract 387

8:30 SAFE OTC: A COMMUNITY EDUCATION CAMPAIGN IN POWELL, WY.

CV Jackson, Seattle, WA. University of Washington School of Medicine

Abstract 388

8:45 EVALUATION OF A COMMUNITY-BASED HEALTH EDUCATION INTERVENTION TO IMPROVE EARLY CHILDHOOD NUTRITION IN RURAL KENYA.

L Matheson, S Walton, N Kotadia, D Webster and V Kapoor, Vancouver, BC, Canada. University of British Columbia

Abstract 389

9:00 EVALUATION OF HAND HYGIENE KNOWLEDGE, PRACTICES, AND BARRIERS IN RURAL UGANDA. PJ Hemmons, T Okuda, V Fung, A Geddes and V Kapoor, Vancouver, BC, Canada. University of British Columbia

Abstract 390

9:15 HELPING THE PRE-DIABETIC AND OVERWEIGHT OF MILES CITY ACCESS THE RESOURCES TO PREVENT DIABETES.

B Murphy, Seattle, WA. University of Washington

Abstract 391

9:30 EXPANDING ACCESS OF INTRANASAL NALOXONE TO COLUMBIA COUNTY EMERGENCY

MEDICAL TECHNICIANS.

T Hughes, Spokane, WA. University of Washington

Abstract 392

9:45 TATTOO REGULATIONS: PERMANENT REGULATIONS TO GET INKED IN BUFFALO, WYOMING.

M Johnson, Seattle, WA. University of Washington School of Medicine

Abstract 393

Endocrinology and Metabolism III

Bingham Room \#3 (Sunset Center)

Kristina M. Utzschneider and Katya Rubinow, Presiding

8:00 TWO NEW GENES INVOLVED IN LIPID METABOLISM?

JM Yaghoubian, N Ehrhardt, JW Burke, U Tan, M Peterfy and S Fuchs, Los Angeles, CA and Pomona, CA. Western

University of Health Sciences (WAFMR/WAP Student Subspecialty Award Winner)

Abstract 394 
8:15 LOW INHIBIN B CORRELATES WITH FEATURES OF METABOLIC SYNDROME IN PREPUBERTAL BOYS WITH KLINEFELTER SYNDROME.

$S$ Davis, N Lalou, M Bardsley, M Temple, K Kowal and J Ross, Aurora, CO; Paris, France and Philadelphia, PA. University of Colorado (WAFMR Scholar Awardee)

Abstract 395

8:30 EXPLORING THIOREDOXIN INTERACTING PROTEIN REGULATED METABOLISM IN ANAPLASTIC THYROID CANCER.

LJ Hostetter, J Morrison, V Sharma, J Severson and B Haugen, Denver, CO. University of Colorado Denver School of Medicine

Abstract 396

8:45 MACROPHAGES SECRETE ESTROGENS WITH EVIDENCE FOR POTENTIAL DE NOVO STEROIDOGENESIS.

S Wang, A Chait and K Rubinow, Seattle, WA. University of Washington (WSCI Travel Award Winner)

Abstract 397

9:00 ROLE OF LIPOPROTEIN LIPASE IN NEURONS OF THE BRAIN.

I Rudenko, K Bruce, H Wang and R Eckel, Denver, CO. University of Colorado School of Medicine

Abstract 398

9:15 CONTROL OF LIPID DROPLET SIGNALING IN MURINE SPERMATOZOA.

$B$ Tully, J Duke, K Roberts and T Chauvin, Seattle, WA and Spokane, WA. University of Washington School of Medicine

Abstract 399

9:30 ADRENAL INSUFFICIENCY IN EOSINOPHILIC ESOPHAGITIS PATIENTS TREATED WITH SWALLOWED TOPICAL STEROIDS.

H Rahat, C Wood, G Furuta, D Atkins and S Hsu, Aurora, CO. Children’s Hospital Colorado

Abstract 400

9:45 MODY3 AND DIABETES TYPE 2 COMBINE TO YIELD STUBBORN BLOOD SUGAR MANAGEMENT.

$J$ Vercollone, Seattle, WA. University of Washington

Abstract 401

General Internal Medicine and Aging

Babcock \#6 (Sunset Center)

David Schade, Presiding

8:00 A RARE COMPLICATION OF A COMMON OBESITY PROCEDURE.

L Ereifej, R Crowell and D Schade, Albuquerque, NM. University of New Mexico

Abstract 402

8:15 DOES ASTHMA INCREASE CARDIOVASCULAR RISK IN TYPE 2 DIABETES?

MD Ehrhart, C Murray-Krezan, F Qeadan and MR Burge, Albuquerque, NM. University of New Mexico

Abstract 403

8:30 MORTALITY DIFFERENTIALS IN U.S. CHINESE AND JAPANESE NATIVES AND IMMIGRANTS

COMPARED TO RESPECTIVE COUNTRIES OF ORIGIN: 2003-2011.

K Hastings, D Boothroyd, K Eggleston, M Cullen and L Palaniappan, Oakland, CA. Stanford University

Abstract 404

8:45 PHYSICAL ACTIVITY, BODY FATNESS, AND VISCERAL ADIPOSITY IN OVERWEIGHT LATINO AND NON-LATINO ADULTS.

NA Cameron, J Godino, J Nichols, D Wing, L Hill and K Patrick, La Jolla, CA. University of California, San

Diego School of Medicine

Abstract 405 
9:00 PSYCHOSOCIAL INDICATORS AND PHYSICAL ACTIVITY AND FUNCTIONING IN A COHORT OF COMMUNITY DWELLING OLDER ADULTS.

I Lin, D Coon, K O’Connor, M Malek-Ahmadi and J Mohler, Tucson, AZ; Phoenix, AZ and Sun City, AZ. University of Arizona (WAFMR/WAP Student Subspecialty Award Winner)

Abstract 406

9:15 SAD, ANXIOUS, AND PLANNING FOR THE FUTURE: ARE DEPRESSION AND ANXIETY ASSOCIATED WITH ADVANCE CARE PLANNING?

Y Ramos, R McMahan, R Ramos, S Osua and R Sudore, MD, Seattle, WA and San Francisco, CA. University of Washington School of Medicine

Abstract 407

9:30 REASONS FOR DISCHARGE FROM A LARGE OPIOID PRESCRIBING REGISTRY: A RETROSPECTIVE ANALYSIS.

MS Novack, J James, S Jackson, C McKinney, J Merrill and J Klein, Spokane, WA and Seattle, WA. University of Washington School of Medicine

Abstract 408

9:45 CANCELLED

Abstract 409

Neonatology General V

Carpenter Hall

Jae Kim and Thomas Shimotake, Presiding

8:00 THE CHANGING PATTERN OF PROCEDURES PERFORMED IN NEWBORNS IN THE STATE OF CALIFORNIA.

T Stavroudis, T Chavez, PS Friedlich, A Garingo, FB Wertheimer and A Lakshmanan, Los Angeles, CA. Children's Hospital Los Angeles and LAC+USC Medical Center, Keck School of Medicine, University of Southern California

Abstract 410

8:15 UTILIZATION PATTERNS OF EXTRACORPOREAL MEMBRANE OXYGENATION IN NEONATES IN THE UNITED STATES 1997-2012.

A Song, R Chapman, PS Friedlich and A Lakshmanan, Los Angeles, CA. Children’s Hospital Los Angeles

Abstract 411

8:30 RESOURCE UTILIZATION FOR NEONATES WITH CONGENITAL DIAPHRAGMATIC HERNIA IN THE UNITED STATES 1997-2012.

A Song, PS Friedlich, R Chapman, R Burke, J Upperman, J Stein and A Lakshmanan, Los Angeles, CA. Children's

Hospital Los Angeles

Abstract 412

8:45 EPIDIMIOLOGY OF APPARENT LIFE THREATENING EVENTS (ALTE) IN INFANTS IN CALIFORNIA. ED Deribssa, A Lakshmanan, J Shepherd, PS Friedlich, A Mikhail and A Song, Los Angeles, CA. University of Southern California

Abstract 413

9:00 PATTERNS AND PREDICTORS OF RESOURCE UTILIZATION IN NEONATES RECEIVING

EXTRACORPOREAL MEMBRANE OXYGENATION IN THE STATE OF CALIFORNIA FROM 2006-2010.

G Chen, A Song, A Lakshmanan, PS Friedlich and R Chapman, Arcadia, CA and Los Angeles, CA. University of

Southern California

Abstract 414

9:15 HOSPITAL MANAGEMENT OF PATENT DUCTUS ARTERIOSUS IN CALIFORNIA.

$S$ Ngo, J Profit, J Gould and HC Lee, Berkeley, CA and Palo Alto, CA. University of California, Berkeley

Abstract 415 
9:30 EVALUATION OF BIRTH ATTENDANT COMPLIANCE WITH RATIONAL IMMEDIATE NEBORN CARE AND NEONATAL ASPHYXIA INTERVENTION PRACTICES IN AN INDIAN PEDIATRIC HOSPITAL.

C Orlando, A Allen, M Parkinson, D Shapiro and B Fassl, Centerville, UT. University of Utah School of Medicine

Abstract 416

9:45 SERIAL FOLLOW UP OF MENTAL HEALTH IN LOW-INCOME MOTHERS AFTER NICU DISCHARGE. NG Lynch, AM Yeh, A Diamond, N Flores, J Eshagian, R Polcyn, A Pham, M Williams, DL Vanderbilt, PS Friedlich and A Lakshmanan, Los Angeles, CA. Children's Hospital Los Angeles and LAC+USC Medical Center, Keck School of Medicine of University of Southern California

Abstract 417

Neonatology - Perinatal Biology II

Studio 105 (Sunset Center)

Laura D. Brown and Kurt Albertine, Presiding

8:00 PRE-ECLAMPSIA AND INFLAMMATORY PRETERM LABOR ALTER THE HUMAN PLACENTAL HEMATOPOIETIC NICHE.

KL Ponder, A Bárcena, FL Bos, M Gormley, Y Zhou, K Ona-Vu, M Kapidzic, AC Zovein and SJ Fisher, San Francisco, CA. University of California, San Francisco

Abstract 418

8:15 ADIPONECTIN SUPPLEMENTATION IN PREGNANT MICE IMPROVES GLUCOSE TOLERANCE IN OFFSPRING.

M Gossling, FJ Rosario, T Jansson and T Powell, Aurora, CO. University of Colorado (WSPR Mead Johnson Travel Award Winner)

Abstract 419

$8: 30$

UNIVERSITY OF COLORADO FRED BATTAGLIA STATE-OF-THE-ART SPEAKER INTERPRETING PERINATAL CARDIAC GROWTH.

Sonnet Jonker, Oregon Health Sciences Center

9:00 SYNCHRONOUS ABERRANT CEREBELLAR AND OPERCULAR DEVELOPMENT IN FETUSES AND NEONATES WITH CONGENITAL HEART DISEASE.

A Wong, T Chavez, H Lai, L Paquette and A Panigrahy, Los Angeles, CA, Valhalla, NY and Pittsburgh, PA. New York Medical College

Abstract 420

9:15 SERIAL CEREBELLAR AND OPERCULAR STRUCTURAL DEVELOPMENT OF FETUSES AND NEONATES WITH CONGENITAL HEART DISEASE (CHD) CORRELATED WITH EARLY NEURODEVELOPMENTAL OUTCOMES.

A Wong, S O’Neil, T Chavez, H Lai, A Panigrahy and L Paquette, Los Angeles, CA, Valhalla, NYand Pittsburgh, PA. New York Medical College

Abstract 421

9:30 ANTENATAL VITAMIN D PRESERVES PLACENTAL WEIGHT AND VESSEL DENSITY AND FETAL GROWTH AFTER INTRA-AMNIOTIC ENDOTOXIN EXPOSURE.

MW Cookson, R Sharon, G Seedorf, B Dodson, SH Abman and E Mandell, Denver, CO and Aurora, CO.

University of Colorado

Abstract 422

9:45 THE USE OF HEPATOBILIARY SCINTIGRAPHY IN DIAGNOSING BILIARY ATRESIA IN INFANTS WITH CONJUGATED HYPERBILIRUBINEMIA WHO RECEIVED PARENTERAL NUTRITION.

K Barseghyan, C McLean, T Chavez and R Ramanathan, Los Angeles, CA. LAC+USC

Abstract 423 
Pulmonary and Critical Care II

Promenade Lobby (Sunset Center)

Philippe Montgrain, Presiding

PRESENTING ILLNESS AND MORTALITY OUTCOMES IN PATIENTS INTUBATED IN THE EMERGENCY DEPARTMENT.

J Yeaton, AE Pickering, T Durns, R Miller, Z Roward and L DeLuca, Tucson, AZ. University of Arizona

8:15 THE EFFECT OF PRESENTING COMPLAINT ON THE RISK OF DEVELOPING VENTILATOR-ASSOCIATED PNEUMONIA FOR PATIENTS INTUBATED IN AN ACADEMIC EMERGENCY DEPARTMENT.

AE Pickering, J Yeaton, T Durns, R Miller, Z Roward and L DeLuca, Tucson, AZ and Tucson, AR. University of Arizona Tucson

Abstract 425

8:30 GENETIC NETWORK IDENTIFICATION, INTERACTION, AND VARIABLE EXPRESSION IN MUC5B VARIANT IDIOPATHIC PULMONARY FIBROSIS.

K Lind, A Walts, A Thor, I Yang and D Schwartz, Greenwood Village, CO. University of Colorado School of Medicine (WAFMR/WAP Student Subspecialty Award Winner)

Abstract 426

8:45 IN VIVO MEASUREMENT OF MOUSE ENDOTHELIAL SURFACE LAYER IN SURFACE CORTICAL MICROVASCULATURE.

MJ Perez, J Ford, Y Yang and E Schmidt, Denver, CO. University of Colorado School of Medicine

9:00 EXPLORING THE ANTI-INFLAMMATORY EFFECTS OF THE AMYLOIDOGENIC HEXAPEPTIDE, AMYLIN28-33, IN SEPSIS.

S Mahapatra, M Kurnellas, J Rothbard, D Cornfield and L Steinman, Palo Alto, CA; Omaha, NE and Stanford, CA. Stanford University Medical Center (WSCI Travel Award Winner)

9:15 UNIQUE RAT STRAIN THAT SURVIVES BREATHING HYPEROXIA ALSO RESISTS OBESITY.

K Repine, PV Wilson, N Elkins, J Newman, Q He, KA Baer, J Torres, A Newman, A Fernandez-Bustamante and JE Repine, Aurora, CO. Webb-Waring Center, University of Colorado Anschutz Medical Center

Abstract 429

$9: 30$

State-of-the-Art Speaker

LUNG CANCER IN WOMEN.

Philippe R. Montgrain, VA San Diego / UC San Diego Health

Surgery IV

Green Room (Sunset Center)

Laurel Desnick and Ryan Hall, Presiding

8:00 DOES PREOPERATIVE VITAMIN D DEFICIENCY PREDICT POSTOPERATIVE HYPOCALCEMIA AFTER THYROIDECTOMY?

E Alkhalili, MD Ehrhart and MR Burge, Albuquerque, NM. University of New Mexico

Abstract 430

8:15 UTILITY OF A PORCINE MODEL OF POLYMETHYL METHACRYLATE SPREAD DURING KYPHOPLASTY OR VERTEBROPLASTY.

J Frankl, M Sakata, A Peterson and C Hennemeyer, Tucson, AZ. University of Arizona College of Medicine

Abstract 431 
8:30 ASSESSMENT AND COMPARISON OF VACCINATION STATUS IN PEDIATRIC COCHLEAR IMPLANT PATIENTS: A 10 YEAR RETROSPECTIVE REVIEW.

C Jin, P Téllez, D Lu, J Pauwels, S Dobson and FK Kozak, Vancouver, BC, Canada. University of British Columbia

Abstract 432

8:45 THE "SIMPLE" CHECKLIST: A CRITICAL APPRAISAL TOOL FOR REVIEWING THE MEDICAL LITERATURE AT JOURNAL CLUB AND BEYOND.

$N$ Wierks, A Knox and J Arneja, Vancouver, BC, Canada. University of British Columbia

Abstract 433

9:00 TIMELY EMERGENCY AND URGENT SURGERY ACCESS FOR ACUTELY ILL PEDIATRIC PATIENTS: A RETROSPECTIVE REVIEW.

S Kim and S Butteworth, Vancouver, BC, Canada. BC Children's Hospital

Abstract 434

9:15 IN VIVO ULTRASOUND ELASTICITY IMAGING CLASSIFIES HEALTHY AND DISEASED POSTERIOR TIBIAL TENDONS.

J Klewer, L Gao, J Guerra, J Szivek, M Taljanovic, L Latt and R Witte, Tucson, AZ. University of Arizona

Abstract 435

9:30 THE ROLE OF ALDOSE REDUCTASE IN THE DEVELOPMENT OF POSTERIOR CAPSULAR OPACIFICATION IN A MOUSE MODEL OF CATARACT SURGERY.

L Zukin, M Pedler and JM Petrash, Greenwood Village, CO and Aurora, CO. University of Colorado Denver

Abstract 436

9:45 TISSUE EXPANSION IN PEDIATRIC PATIENTS: A 10-YEAR REVIEW.

L Bjornson, M Bucevska and C Verchere, Kingston, ON, Canada and Vancouver, BC, Canada. Queen's University Abstract 437 


\section{CONCURRENT SESSIONS}

Saturday, January 30, 2016

10:15 AM - 11:45 AM

Jointly sponsored by

\section{WESTERN SECTION AMERICAN FEDERATION FOR MEDICAL RESEARCH \\ WESTERN SOCIETY FOR CLINICAL INVESTIGATION \\ WESTERN ASSOCIATION OF PHYSICIANS \\ WESTERN SOCIETY FOR PEDIATRIC RESEARCH \\ WESTERN STUDENT MEDICAL RESEARCH FORUM}

Adolescent Medicine and General Pediatrics IV $\ldots \ldots \ldots \ldots \ldots \ldots \ldots \ldots \ldots \ldots \ldots \ldots$ Rehearsal Room

Health Care Research III . . . . . . . . . . . . . . . . . . . . . . . . . . . . . . . . . . .

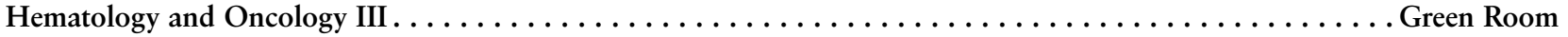

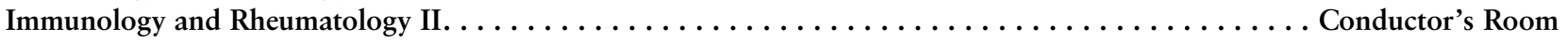

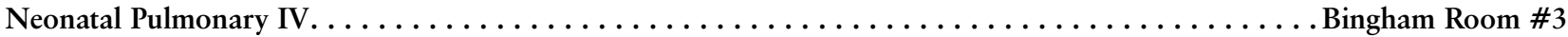

Neonatology General VI . . . . . . . . . . . . . . . . . . . . . . . . . . . . . . . . . . .

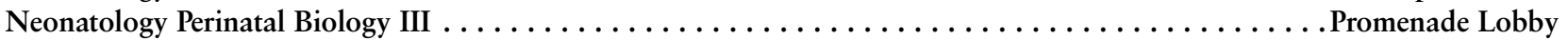

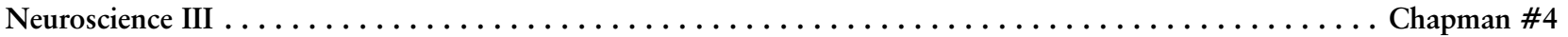

Adolescent Medicine and General Pediatrics IV

Rehearsal Room (Sunset Center)

Samrat U. Das and Mary Ramos, Presiding

10:15 TESTING THE UTILITY OF STANDARDIZED INTERVIEWS FOR RESIDENCY SELECTION BY DIVIDING THE STANDARDIZED QUESTIONS AMONGST MULTIPLE INTERVIEWERS.

SU Das and ME Bar-on, Las Vegas, NV. University of Nevada School of Medicine

Abstract 438

10:30 SOCIAL MEDIA: AN EFFECTIVE METHOD OF ATTRACTING THE MODERN RESIDENCY APPLICANT.

C Casilang and S Mehra, Fresno, CA. University of California, Fresno

Abstract 439

10:45 STRETCHING EFFECT ON CHANGES IN ACHILLES TENDON CROSS-SECTIONAL AREA IN RUNNERS.

C Neves, A Johnson and I Hunter, Seattle, WA and Provo, UT. University of Washington School of Medicine

Abstract 440

11:00 PEDIATRIC EXPOSURES TO DISHWASHER AND LAUNDRY DETERGENTS: 2013-2014.

M Davis, M Casavant, H Spiller, T Chounthirath and G Smith, Seattle, WA and Columbus, OH. Nationwide

Children's Hospital

Abstract 442

11:15 A WELL ORGANIZED SYSTEMATIC APPROACH TO INCREASE RESIDENT SCHOLARSHIP.

SU Das and ME Bar-on, Las Vegas, NV. University of Nevada School of Medicine

Abstract 443

Health Care Research III

Babcock \#6 (Sunset Center)

Leo S. Morales, Presiding

10:15 IMPROVING ASTHMA CARE IN A PEDIATRIC TEACHING CLINIC.

J Lee, A Gogo, D Tancredi and U Shaikh, Sacramento, CA. University of California, Davis Medical Center (WSCI Travel Award Winner) 
10:30 USABILITY TESTING OF THE BURN SURVIVAL KIT WITH HEALTHCARE PROVIDERS IN UGANDA. A Ribeiro, A Maccan, A Rajwani, J Huebner, M Caulfield, MM Ajiko, N O'Hara and R Evans, Vancouver, BC, Canada and Soroti, Uganda. University of British Columbia

Abstract 445

10:45 OCCUPATION-RELATED DIFFERENCES IN HEMOGLOBIN A1C IN A PREDOMINANTLY HISPANIC POPULATION.

A Manshad, JR Bucheli and MR Burge, Albuquerque, NM. University of New Mexico

Abstract 446

11:00 A METHOD FOR MULTISTAGE SAMPLING IN THE RANDOMIZATION OF HOUSEHOLD SURVEYS IN DEVELOPING COUNTRIES.

MD Caulfield, A Rajwani, AS Maccan, J Huebner, A Ribeiro, MM Ajiko, N O’Hara and R Evans, Vancouver, BC, Canada; California, CA and Soroti, Uganda. University of British Columbia

Abstract 447

11:15 UNDERREPRESENTED MINORITY (URM) MEDICAL STUDENT PERSPECTIVES ON RETENTION AND ADVANCEMENT.

AJ Smith, C Solomon and LS Morales, Seattle, WA. University of Washington School of Medicine

Abstract 448

11:30 PRIMARY CARE PROVIDERS’ PERCEPTIONS OF DIABETES PREVENTION PROGRAMS.

EC Vasti, S Tsoi and T Moin, Los Angeles, CA. VA Greater Los Angeles Healthcare System

Abstract 449

Hematology and Oncology III

Green Room (Sunset Center)

Thomas Deloughery, Presiding

10:15 CHARACTERIZATION OF A CUSTOM MONOCLONAL ANTIBODY AS A NOVEL TUMOR BIOMARKER IN HUMAN GASTROINTESTINAL CANCERS.

JS Ryan, Q Wang, D Wu, Z Dong and P Wu, Seattle, WA. University of Washington School of Medicine

Abstract 450

10:30 LIPOPLEX DELIVERY OF MICRO-RNA 200C TO OVARIAN CANCER CELLS.

L Smith, M Gordon, JL Betker, TJ Anchordoquy and JK Richer, Denver, CO and Aurora, CO. University of

Colorado AMC

Abstract 451

10:45 PHYSICIAN-PATIENT DISAGREEMENT ON EASTERN COOPERATIVE ONCOLOGY GROUP PERFORMANCE STATUS IS ASSOCIATED WITH INCREASED MORTALITY IN PATIENTS WITH HEMATOLOGIC MALIGNANCIES.

MA Liu, T Hshieh, N Condron, M Wadleigh, P Armand, G Abel and JA Driver, Tucson, AZ and Boston, MA.

University of Arizona College of Medicine

Abstract 452

11:00 DEVELOPMENT OF OPTIMIZED PROTOCOL FOR GENERATION OF NATURAL KILER CELLS EXPRESSING CHIMERIC ANTIGEN RECEPTORS FROM HEMATOPOIETIC STEM CELLS FOR CANCER IMMUNOTHERAPY.

A Patel, L Truscott and SN De Oliveira, Pomona, CA and Los Angeles, CA. Western University of Health Sciences

Abstract 453

11:15 CHARACTERIZING THE IMMUNE MICROENVIRONMENT OF MALIGNANT PERIPHERAL NERVE SHEATH TUMORS IN ORDER TO GUIDE IMMUNOTHERAPY.

S Jensen, A Singh, S Dry, B Chmielowski, N Federman, F Eilber and E Shurell, Los Angeles, CA. David Geffen

School of Medicine at UCLA

Abstract 454 


\section{Western Meeting Program}

11:30 THE BIOLOGY OF MUCIN-2 (MUC2) IN BREAST CANCER.

A Astashchanka and B Jacobsen, Aurora, CO. University of Colorado School of Medicine

Immunology and Rheumatology II

Conductor's Room

Kevin Deane and Keith K. Colburn, Presiding

10:15 PHENOTYPE OF HUMAN REGULATORY T CELLS EXPRESSING FOXP3 SPLICE VARIANTS.

M Maurano and SF Ziegler, Seattle, WA. University of Washington

10:30 ANTI-CYCLIC CITRULLINATED PROTEIN ASSAYS AND THE FUTURE DEVELOPMENT OF RHEUMATOID ARTHRITIS.

SL Dill, K Deane and ED Jess, Bethesda, MD and Aurora, CO. University of Colorado (WSCI Travel Award Winner)

Abstract 457

10:45 TRANSCRIPTOME ANALYSIS OF PSORIASIS AND WOUNDED SKIN.

SX Chen, K Chun, T Hata and R Gallo, La Jolla, CA. University of California, San Diego

Abstract 458

11:00 DELAYED RECOGNITION OF HYPER IGD SYNDROME LEADS TO PROLONGED INCORRECT MEDICAL CARE.

B Jagadesan, M Hogan and NW Wilson, Las Vegas, NV. University of Nevada School of Medicine

$11: 15$

State-of-the-Art Speaker

MUCOSAL INFLAMMATION IN THE PATHOGENESIS OF RHEUMATIC DISEASES.

Kristine Kuhn, University of Colorado School of Medicine

Neonatal Pulmonary IV

Bingham Room \#3 (Sunset Center)

Adam J. Czynski and Yona Nicolau, Presiding

10:15 EARLY POSTNATAL STEROID USE IN PREMATURE INFANTS AND THE RISK FOR NECROTIZING ENTEROCOLITIS: A COMPREHENSIVE REVIEW.

G Heredia, A Patel, C Chung, J Yao, K Sahrai, P Sathe, Y Michael and B Afghani, Santa Ana, CA and Orange, CA. University of California, Irvine

Abstract 460

10:30 THE ASSOCIATION OF CARDIOPULMONARY RESUSCITATION AND PATENT DUCTUS ARTERIOUSUS IN NEWBORNS.

T Chavez, T Stavroudis, PS Friedlich, A Garingo, J Shepherd and A Lakshmanan, Los Angeles, CA. Children's Hospital Los Angeles and LAC+USC Medical Center, Keck School of Medicine, University of Southern California

Abstract 461

10:45 EARLY CUMULATIVE SUPPLEMENTAL OXYGEN (O2) EXPOSURE PREDICTS BRONCHOPULMONARY DYSPLASIA (BPD) IN EXTREMELY LOW GESTATIONAL AGE NEWBORNS (ELGAN).

K Wai, MA Kohn, R Ballard, D Black and RL Keller, San Francisco, CA. University of California, San Francisco

Abstract 462 
11:00 RESPONSE TO METHOCHOLINE IN NORMAL TERM LAMBS ASSESSED BY FORCED OSCILLATION TECHNIQUE.

Veneroni, M Dahl, K Zuspan, A Lavizzari, S Bowen, D Null, B Yoder, K Albertine and R Dellaca', Salt Lake City, UT, Milan, Italy and Davis, CA. University of Utah

Abstract 463

11:15 RESOURCE UTILIZATION IN THE STATE OF CALIFORNIA FOR NEONATES WITH CONGENITAL DIAPHRAGMATIC HERNIA 2006-2010.

A Song, PS Friedlich, R Chapman, R Burke, J Upperman, J Stein and A Lakshmanan, Los Angeles, CA. Children's Hospital Los Angeles

Abstract 464

11:30 PREVALENCE OF DIAGNOSES ASSOCIATED WITH CHILDREN'S INTERSTITIAL LUNG DISEASE IN THE UNITED STATES 2012.

CA Ulloa, A Song, A Lakshmanan, P Friedlich and N Iyer, Chatsworth, CA. Children's Hospital Los Angeles Abstract 465

\section{Neonatology General VI}

Carpenter Hall

Robert W. DiGeronimo and Kara L. Calkins, Presiding

10:15 SHORT-TERM OUTCOMES OF NEONATES WITH MILD HYPOXIC-ISCHEMIC ENCEPHALOPATHY AFTER THERAPEUTIC HYPOTHERMIA.

M Kirkley, S Kaseman, J Gralla, D Melara, T Grover and C Delaney, Aurora, CO. University of Colorado

Abstract 466

10:30 BEDSIDE BLOOD GAS VS. LABORATORY ANALYSIS OF SODIUM: IS THERE A DIFFERENCE?

T Glasberg, T Chavez, R Ramanathan and A Garingo, Los Angeles, CA. University of Southern California

Abstract 467

10:45 QUALITY REPORT VIEWING BY NEONATAL PROVIDERS AND RELATIONSHIP TO QUALITY INDICATORS.

N Wahid, M Bennett, J Gould, J Profit and HC Lee, Irvine, CA and Stanford, CA. University of California, Irvine

11:00 THE IMPACT OF PREMATURITY ON LOW-INCOME FAMILIES AFTER NICU DISCHARGE: IDENTIFYING MODIFIABLE PREDICTORS.

AM Yeh, NG Lynch, A Diamond, N Flores, R Polcyn, J Eshagian, DL Vanderbilt, PS Friedlich and A Lakshmanan, Los Angeles, CA. Children's Hospital Los Angeles and LAC+USC Medical Center, Keck School of Medicine of University of Southern California

Abstract 469

11:15 THE ASSOCIATION OF THE PATIENT HEALTH QUESTIONNAIRE-2 WITH HEALTH-RELATED QUALITY OF LIFE MEASURES IN LOW-INCOME MOTHERS AFTER NICU DISCHARGE.

A Diamond, AM Yeh, N Lynch, N Flores, J Eshagian, R Polcyn, A Pham, DL Vanderbilt, P Jackson, PS Friedlich and A Lakshmanan, Los Angeles, CA. Children's Hospital Los Angeles and LAC+USC Medical Center, Keck School of Medicine of University of Southern California

Abstract 470

11:30 ASSISTED HOME FEEDING: PREVALENCE AND RISK FACTORS IN NEONATES AT DISCHARGE FROM THE NICU.

$B$ White, C Zang, AP Presson, K Friddle and R DiGeronimo, Salt Lake City, UT. University of Utah School of Medicine

Abstract 471 
Neonatology Perinatal Biology III

Promenade Lobby (Sunset Center)

Sonnet Jonker and Mariana Baserga, Presiding

10:15 NORMALIZATION OF N-3 FATTY ACIDS DURING WEANING PROTECTS AGAINST TRANSFER OF MATERNAL WESTERN STYLE DIET INDUCED DYSBIOSIS AND INFLAMMATION.

TK Soderborg, J Friedman, D Lemas, S Santorico, B De la Houssaye, RC Janssen and D Frank, Aurora, CO.

University of Colorado Anschutz

Abstract 472

10:30 INSIGHTS INTO PROTECTION FROM HYPOXIC INJURY FROM A ZEBRAFISH GENETIC MODEL.

FB Imam, La Jolla, CA. University of California, San Diego

Abstract 473

10:45 MATERNAL TOBACCO SMOKE EXPOSURE SEX-SPECIFICALLY DECREASES LIVER DESATURASE AND ELONGASE ENZYME MRNA LEVELS IN THE RAT.

K Goodwin, C Weinheimer and L Joss-Moore, Salt Lake City, UT. University of Utah

Abstract 474

11:00 LUNG SETD8 MRNA EXPRESSION PEAKS DURING ALVEOLAR FORMATION IN THE RAT.

JT Zhao, Y Yang, R Knecht and L Joss-Moore, Sandy, Salt Lake City, UT. University of Utah

Abstract 475

11:15 CEREBRAL VENTRICULAR VOLUMES IN FETUSES AND NEONATES WITH CONGENITAL HEART

DISEASE: A LONGITUDINAL STUDY.

C Hayek, V Rajagopalan, J Meouchy and L Paquette, Los Angeles, CA. LAC+ USC Medical Center

Abstract 476

Neuroscience III

Chapman \#4 (Sunset Center)

Marie-Francoise Chesselet, Presiding

10:15 NEURON-TARGETED CAVEOLIN-1 ATTENUATES TRAUMATIC BRAIN INJURY-MEDIATED MOTOR AND COGNITIVE DEFICITS.

ES Posadas, J Egawa, J Schilling, P Patel and B Head, San Marcos, CA and San Diego, CA. University of

California, San Diego (WAFMR/WAP Student Subspecialty Award Winner)

Abstract 477

10:30 HIERARCHICAL PROCESSING OF VISUAL STIMULI IN INDIVIDUALS WITH NEPHROPATHIC

CYSTINOSIS AND OBLIGATE HETEROZYGOTES.

AV Sathappan and D Trauner, La Jolla, CA. University of California, San Diego

Abstract 478

10:45 RELIABILITY AND VALIDITY OF THE 6-MINUTE WALK TEST AS AN OUTCOME MEASURE IN OCULOPHARYNGEAL MUSCULAR DYSTROPHY.

M Fernandez and S Youssof, Tucson, AZ and Albuquerque, NM. The University of Arizona

Abstract 479

11:00 CHARACTERIZATION OF NEURONS EXPRESSING DELTA AND MU OPIOID RECEPTORS IN DESCENDING PAIN CONTROL.

SA Low and G Scherrer, Tucson, AZ and Palo Alto, CA. University of Arizona

Abstract 480

11:15 State-of-the-Art Speaker

FROM GUT TO BRAIN: WHAT IS NEW IN PARKINSON'S DISEASE?

Marie-Francoise Chesselet, University of California, Los Angeles 


\section{Officers 2015-2016}

Western Section American Federation for Medical Research

CHAIR

Kristina Utzschneider

University of Washington

PAST PRESIDENT

Michael Schivo

University of California, Davis

Mary Beth Hogan

University of Nevada

Las Vegas
CHAIR-ELECT

Philippe Montgrain

University of California San Diego

\section{COUNCILORS}

Jason Adams

University of California, Davis

Sidharth Mahapatra

University of Nebraska
SECRETARY/TREASURER

Samrat Das

University of Nevada

Las Vegas

Amir Goldkorn

University of Southern California

Ellen Schur

University of Washington

Western Society for Clinical Investigation

\section{PRESIDENT}

Frederick S. Buckner

University of Washington

Keith Colburn

Loma Linda University

Neda Rasouli

University of Colorado- Denver
PAST PRESIDENT

Stephanie Page

University of Washington

COUNCILORS

April Stempien-Otero

University of Washington

Charles Edelstein

University of Colorado-Denver
PRESIDENT

Ravi Durvasula

University of New Mexico

Joshua Goldhaber

Cedars-Sinai Heart Institute

Western Association of Physicians

PRESIDENT-ELECT
W. Conrad Liles
University of Washington
COUNCILORS
Peter Ganz
University of California, San Francisco
Jane Reusch
University of Colorado-Denver

PRESIDENT-ELECT

University of Washington

Jane Reusch

University of Colorado-Denver
SECRETARY/TREASURER

Kevin D. O'Brien

University of Washington

Michele Hamilton

Cedars-Sinai Medical Center

Mark Unruh

University of New Mexico

Western Society for Pediatric Research

\section{PRESIDENT}

Paul Rozance

University of Colorado

SECRETARY/TREASURER

Christian Con Yost

University of Utah
Arlin Blood

Loma Linda University

Josephine Encisco

University of California, Los Angeles

Laura Brown

University of Colorado

\section{PRESIDENT-ELECT}

Alberta Kong

University of New Mexico

OF COUNCIL

Bill Hay, Jr.

University of Colorado

OF COUNCIL

Robin Ohls

University of New Mexico

COUNCILORS

Henry Lee

Stanford University

Erika Fernandez

University of California, San Diego

Craig Wong

University of New Mexico

\section{SECRETARY/TREASURER}

W. Conrad Liles

University of Washington

Robert Ross

University of California, San Diego

PAST PRESIDENT

Kurt Albertine

University of Utah

OF COUNCIL

Marilyn C. Jones

Children's Hospital, San Diego

Echezona Ezeanolue University of Nevada Nicole Tartaglia University of Colorado

Margaret Adam University of Washington 
Western Student Medical Research Forum Officers

2015-2016 Chair

Taylor Soderborg

University of Colorado Denver
2015-2016 Vice-Chair

S. Ryan Hall

University of Washington School of Medicine

Executive Director

Mary Lou Siebert

University of Washington School of Medicine
Program Directors

Laurel Desnick

University of Washington School of Medicine Jorge Nieva

University of Southern California

\section{INDEX TO WESTERN PRESENTED ABSTRACTS}

THURSDAY, JANUARY 28, 2016

Concurrent Sessions: 12:30 pm-2:30 pm

Abstract No

Abstract No.

Adolescent Medicine and General Pediatrics I

Cardiovascular I

Endocrinology and Metabolism I

Health Care Research I

Immunology and Rheumatology I

Infectious Diseases I

Neonatal Pulmonary I

Neonatology General I

Concurrent Sessions: 3:30pm-6:00 pm

Cardiovascular II

Community Health I

Global Health

Hematology and Oncology I

Neonatal Pulmonary II

Neonatology General II

Neuroscience I

Pulmonary and Critical Care I

Surgery 1

1-8

9-15

16-22

23-30

$31-38$

39-44

45-52

53-60

61-68

69-78

79-88

89-98

99-106

107-116

117-126

127-136

137-146

Welcome Reception and Poster Session

FRIDAY, JANUARY 29, 2016

\section{Joint Plenary Session}

$226-229$

Concurrent Sessions: 12:30 pm-2:30 pm

Adolescent Medicine and General Pediatrics II

$147-225$

Cardiovascular III

230-235

236-243

Endocrinology and Metabolism II

244-249

250-254

Gastroenterology

255-262

263-270

271-278

Neonatology General III

279-286

Neonatology Perinatal Biology I

287-294
Concurrent Session: 3:30 pm-6:00 pm

Behavior and Development 295-302

Community Health II 303-312

Health Care Research II 313-320

Hematology and Oncology II $\quad 321-330$

Infectious Diseases II 331-337

Morphogenesis and Malformations 338-345

Neonatology General IV 346-353

Nephrology and Hypertension 354-359

Neuroscience II 360-367

Surgery III 368-377

SATURDAY, JANUARY 30, 2016

Concurrent Sessions: 8:00 am-10:00 am

Adolescent Medicine and General Pediatrics III 378-385

Community Health III 386-393

Endocrinology and Metabolism III 394-401

General Internal Medicine and Aging 402-409

Neonatology General V 410-417

Neonatology Perinatal Biology II 418-423

Pulmonary and Critical Care II 424-429

Surgery IV $\quad$ 430-437

Concurrent Session: 10:15 am-11:45 am

Adolescent Medicine and General Pediatrics IV 438-443

Health Care Research III 444-449

Hematology and Oncology III 450-455

Immunology and Rheumatology II 456-459

Neonatal Pulmonary IV 460-465

Neonatology General VI 466-471

Neonatology Perinatal Biology III $\quad$ 472-476

Neuroscience III $\quad$ 477-480 